operated by

Union Carbide Corporation

Nuclear Division

$$
\text { for the }
$$

Energy Research and Development Administration

\title{
By
}

\author{
William H. Grams \\ and \\ Paul F. Gnirk \\ October 25,1976
}

This report was prepared by RE/SPEC Inc., under subcontract No. 89Y-22303C with Union Carbide Corporation, Nuclear Division, under Contract No. W-7405-eng-26 with the Energy Research and Development Administration. The subcontract was administered by the office of Waste Isolation, Union Carbide Corporation, Nuclear Division.

\section{RE/SPEC INC.}

P. O. BOX 725 - RAPID CITY, S. D. 57701 - 605/343-7868 


\section{DISCLAIMER}

This report was prepared as an account of work sponsored by an agency of the United States Government. Neither the United States Government nor any agency Thereof, nor any of their employees, makes any warranty, express or implied, or assumes any legal liability or responsibility for the accuracy, completeness, or usefulness of any information, apparatus, product, or process disclosed, or represents that its use would not infringe privately owned rights. Reference herein to any specific commercial product, process, or service by trade name, trademark, manufacturer, or otherwise does not necessarily constitute or imply its endorsement, recommendation, or favoring by the United States Government or any agency thereof. The views and opinions of authors expressed herein do not necessarily state or reflect those of the United States Government or any agency thereof. 


\section{DISCLAIMER}

Portions of this document may be illegible in electronic image products. Images are produced from the best available original document. 


\title{
AN ANALYSIS OF THE CUSTOM DESIGN/FABRICATION/TESTING
}

REQUIREMENTS FOR A T.ARGE-HOLE DRILLING MACHINE FOR USE IN

\section{AN UNDERGROUND RADIOACTIVE WASTE REPOSITORY}

Submitted To

\author{
Office of Waste Isolation \\ Oak Ridge, Tennessee \\ operated by \\ Union Carbide Corporation \\ Nuclear Division \\ for the
}

Energy Research and Development Administration

\author{
$B y$ \\ William H. Grams \\ and \\ Paul F. Gnirk \\ of \\ $R E / S P E C$ InC. \\ Rapid City, South Dakota
}

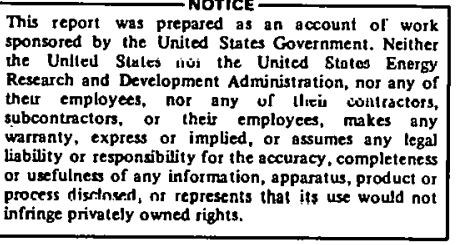

October 25,1976

DISTRIBUTION OF THIS DOCUMENT IS UNLIMITED

This report was prepared as an account of work sponsored by the United States Government. Neither the Unites States nor the Energy Research and Development Administration, nor any of their employees, nor any of their contractors, subcontractors, or their employees, makes any warranty, express or int plied, or assumes any legal liability or responsibility for the accuracy, completeness or usefulness of any information, apparatus, pruduct or process disclosed, or represents that its use would not infringe privately owned rights. Any mention of trade names in this report is for reference purposes only and should not be construed as any manner of endorsement. 


\section{TABLE OF CONTENTS}

Page

1. SUMMARIZED OBJECTIVES AND RESULTS

2. BASIC DESIGN REQUIREMENTS P

3. ELEMENTS OF A CONCEPTUAL DRILLING MACHINE 6

4. SPECIAL CAPABILITIES AND FEATURES OF A CONCEPTUAL 8 DRILLING MACHINE

5. GENERAL ADVANTAGES OF A CUSTOM-DESIGNED DRILLING MACHINE IO

6. CONCEPTUAL PROGRAM PLAN FOR DESIGN, FABRTCATION, AND TESTING 12

7. DRILL PERFORMANCE/COST ANALYSIS . 19

7.1. Drilling Simulation 19

7.2. Input Parameter Specifications for Drill Simulation 23 Studies

7.3. Discussion of Drill simulation Results 28

7.4. Concluding Comments

LIST OF REFERENCES

Appendix A: Simulation Output for the Conceptual Drilling. A-1 Machine 
Figure No.

Page

6.1 Task Definitions for Phases 1 and 2 and Associated

Time Frames

6.2 Task Definitions for Phases 2, 3, and 4 and

Associated Time Frames

7.1 Typical Storage Room for the Alpha Repository, with a Square Pattern of Drillholes

7.2 Conceptual Layout (Snowflake) for the Underground Facilities of the Alpha Repository

7.3 Graphical Representation of the Effect of a Variation in Set-Up Time of the Drilling Machine on Total Cost per Drillhole (Lower-Limit repository Size)

7.4 Graphical Representation of the Effect of a Variation in Drill Steel Addition/Subtraction Time on Total Cost per Drillhole (Lower-Limit Repository Size)

7.5 Graphical Representation of the Effect of Drill Penetration Rate on Total Cost Per Drillhole (Lower-Limit Repository Size)

A.I Graphical Representation of the Timewise Accumulation of Waste Canisters and the Corresponding Accumulation of Drillholes Produced by the Conceptual Drilling Machine

A.2 Graphical Representation of the Projected Annual Drilling Costs (1975 Dollars) for the Conceptual Drilling Machine

A.3 Graphical Representation of the Percentage Operation Time on an Annual Basis for the Conceptual Drilling Machine

\section{LIS $\underline{\underline{T}}$ OF TABLES}

Table No.

$\underline{\text { Page }}$

Special Features of Three Commercial Drilling Machines and the Conceptual Drilling Machine

Tabulation of Estimated Man-Years of Technical Effort and Associated Labor and Material Costs for Design, Fahriration, and Testing of a. Drilling Machine 
(RSI-0047)

\section{LIST OF TABLES (CONT'D)}

Table No.

$\underline{\text { Page }}$
7.1 Input Data for Drill Simulation Studies
7.2 Breakdown of Estimated Costs of the Initial Design, Fabrication, and Testing and Subsequent Production of the Conceptual Drilling Machines for the Alpha Repository (1975 Dollars)

7.3

Breakdown of Drilling Costs for Three Commercial Drilling Machines and the Conceptual Machine as Determined by Drill Simulation Studies for the Upper and Lower Limits of Waste-Container Drillholes for the Alpha Repository

7.4 Breakdown by Unit and Percentage of Capital, Material, and Personnel costs for. Three Commercial Drilling Machines and the Conceptual Drilling Machine, as Determined by Drill Simulation Studies for the Upper and Lower Limits of Waste-Canister Drillholes for the Alpha Repository

\section{FOREWORD}

This report presents an analysis of the fabrication and field test requirements for a drilling machine that would be applicable to the drilling of large diameter holes for the emplacement of radioactive waste canisters in an underground repository. On the basis of a previous study in 1975 by $R E / S P E C$ InC. for the Oak Ridge National Laboratory, it was concluded that none of the commercially-available machines were ideally suited for the desired drilling application, and that it was doubtful whether a machine with the required capabilities would become available as a standard equipment item. The results of the current study; as presented herein, provide a definitive basis for selecting the desired specifications, estimating the design, fabrication, and testing costs, and analyzing the costbenefit characteristics of a custom-designed drilling machine for the emplacement hole drilling task.

This report was prepared under Subcontract No. 4269 with Union Carbide Corporation, Nuclear Division during FY 1976T. The technical contents have been reviewed by Mr. Leo L. Van Sambeek and Mr. Thomas J. Zeller of RE/SPEC InC., and the typing was performed by Ms. Julie $S$. Annicchiarico of RE/SPEC Inc. The report was submitted in draft form to the Office of Waste Isolation for review on nctoher 26, 1976, and $R E / S P E C$ InC. received notification on November 15,1976 that the report was approved for publication without change in the textual content. 


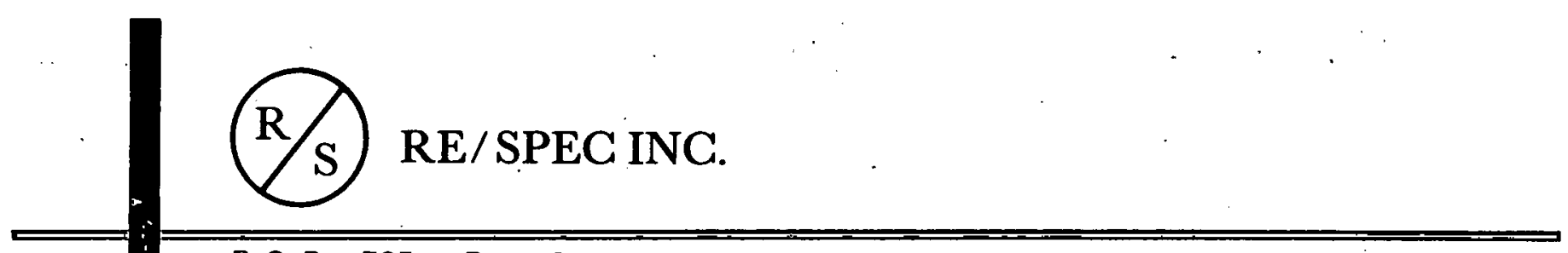

P. O. BOX $725 \bullet$ RAPID CITY, S.D. $57709 \cdot 605 / 343.7868$

October 25, 1976

TECHNICAL MEMORANDUM REPORT RSI-0047

TO: $\quad$ Office of Waste Isolation

P. O. BOX $Y$

Oak Ridye, TN 37830

Attn.: Dr. William C. MCClain

FROM: $\quad$ Mr. William H. Grams

Dr. Paul F. Gnirk

$R E / S P E C$ Inc.

P. O. BOX 725

Rapid City, SD 57709

SUBJECT: "An Analysis of the Custom Design/Fabrication/Testing Reguirements for a Large-Hole Drilling Machine for Use in an Underground Radioactive Waste Repository" (Union Carbide Corporation, Nuclear Division Subcontract No. 4269; RSI/001000/FY76T).

\section{SUMMARIZED OBJECTIVES AND RESULTS}

The storage of canisters of radioactive waste in large diameter, vertical boreholes drilled in the floors of rooms in an underground rcpocitory in salt involves an unusual drilling equipment requirement. The drilling of twenty to thirty inch diameter holes to depths of fifteen to twenty-five feet in rock salt is technically feasible; however, there is probably no commercially available drill which could perform the drilling task efficiently in a storage room with a height of sixteen feet. Commercially available machines, which could possibly perform the large hole drilling task, would require custom design modifications.

The basic objective of this report is to analyze the fabrication and field test roquirements for a drilling machine that is specifically applicablc to the drilling of radioactive-waste canister holes in an mnderground repository. The drilling machine should initially be designed and tested for the high-production drilling of large-diameter holes 
in salt; however, it is felt that the machine should require only minimal modifications for use in such rock types as shale, limestone, basalt, and granite. As demonstrated in this report, the cost-benefit characteristics of a "custom-designed" drill, for this particular type of drilling task, are considerably more attractive than for an "off-shelf" machine with the necessary design modifications.

The motivation for undertaking this study was generated by the results of a previous investigation of the availability and cost of large hole drilling equipment for the excavation of radioactive-waste canister emplacement holes in salt in the conceptual Alpha repository (see Ref. 1 and 2). On the basis of in-depth inquiries to approximately fifteen drilling equipment manufacturers, eight manufacturers responded with equipment that they felt would be capable of performing the drilling task. From these responses, five representative drilling machines were selected for further evaluation. It was subsequently concluded that none of the representative machines were ideally suited for the desired application, and that it was doubtful whether a machine with the required capabilities would become available as standard equipment. The specifications for an applicable machine were outlined, along with some thoughts on the necessary design and fabrication. This current report presents the results of a subsequent in-depth analysis of a conceptual drilling machine that would be particularly suited for the anticipated drilling task, including the desired specifications, design, fabrication, and testing costs, and costbenefit characteristics.

Sertinns 2 and 3 of this report deal with the basic design requirements and desired elements of a conceptual drilling machine. Particular emphasis is placed on the integrated use of off-shelf components, with custom design of features that are strictly directed toward the anticipated drilling task. Section 4 briefly discusses special features and capabilities that could be incorporated into the conceptual drilling machine, as compared to those available or optional on existing machines of a candidate nature. Section 5 discusses the relative merits of a custom-designed machine as compared to modifying an existing candidate machine. Section 6 outlines a conceptual plan for the design, fabrication, and testing of a drilling machine, involving five phases and twenty-one identifiable tasks. In addition, estimated man-hour and cost requirements are presinted. 
Section 7 of this report is devoted to a drill performance/cost analysis, involving the conceptual drilling machine and the three commercial machines that were considered as candidates for drilling some 50,000 to 144,000 canister emplacement holes in the Alpha repository. A drill simulation code was used in conjunction with the mine design/ operation/scheduling characteristics of a conceptual repository layout. It was demonstrated that a cost savings of at least $\$ 2,000,000$ (1975 dollars) may be realized by utilization of a custom-designed drilling machine, as compared to employing any of the other three commercially available candidate machines. The cost savings are primarily due to the anticipated. increase in drilling efficiency of the custom-designed machine. In spite of estimated development costs of $\$ 620,000$ for the first machine, the total capital investment would be of the same order as that for the other commercial machines; basically, one custom-designed machine could accomplish approximately the same amount of drilling as two or more of the commercially available machines. It should be noted that the development costs for the first custom-designed machine and the anticipated unit cost per additional machines are utilized to obtain an average unit cost per machine for purposes of the drill performance/cost analysis. 


\section{BASIC DESIGN REQUIREMENTS}

Any underground mining or construction project places unique constraints on the associated machinery. The properly engineered equipment for use underground should be designed to encompass the following conditions which affect all underground mining situations:

(1) Size constraints due to limited maneuvering space;

(2) Weight and size limitations due to the hoisting capabilities in the main access shaft;

(3) Ventilation requirements;

(4) Noise control;

(5) Dust control;

(6) Fire protection for hydraulic and electrical systems.

of these six major constraints, the federal regulations concerning noise and dust levels are very specific and must be followed closely. Fire protection is also a federal requirement where fire resistant hydraulic fluids are mandatory. The change-over from an existing hydraulic design to one which incorporates fire resistant hydraulic fluids can be very expensive if components, notably high pressure pumps and seals, are incompatible with the special fluids. Automatic fire suppression systems will probably be required in the near future. Falling object protection systems and roll over protection systems are not required, but union regulations and future federal regulations may make these items mandatory. It is more economical to incorporate these options initially, rather than to "field install" them at a later date.

A variety of drilling techniques are applicable, including:

(1) Percussive drilling and compressed air cuttings removal;

(2) Rotary drilling with drag bits and auger cuttings removal;

(3) Rotary drilling with tricone bits and compressed air cuttings removal;

(4) Rotary drilling with drag bits and bucket excavation cuttings removal;

(5) Core drilling.

Although the design and component arrangement of drilling machinery for each of the above techniques would differ considerably, each would incorporate the following basic sub-assemblies: 

(1) Chassis;
(1) Tower/drill rotation/drill steel handling assemblies;
(3) Electrical-hydraulic systems;
(4) Drill steel/bit;
(5) Dust control/cuttings handling systems.

These six main sub-assemblies are in themselves made up of many other components; however, each should be designed or selected with the following general specifications in mind:
(1) Safety;
(2) Ruggedness;
(3) Ease of Operation;
(4) Ease of Maintenance;
(5) Ease of Disassembly/Assembly.

These five major goals of design should be taken into consideration when designing any component or sub-assembly in any driliing machine. 


\section{ELEMENTS OF A CONCEPTUAL DRILLING MACHINE}

A conceptual drilling machine would conceivably be an electricalpowered rotary drill, mounted on a crawler chassis and utilizing either a drag bit or a tricone pilot bit with hole enlarger, air cuttings removal to a hopper or haulage machine, a mechanized drill steel addition/subtraction system, and roof stabilization jacks. A preliminary breakdown of the primary sub-assemblies of the machine, including those components which are off-shelf items and those which must be designed, is presented as follows :

(1) Chassis (Main Frame Assembly)

(a) Crawler Assembly, with such components as grousers, idler assemblies, drive sprockets, return rollers, and bottom rollers: To be purchased as off-shelf components from such companies as Caterpillar, John Deere or International Harvester.

(b) Crawler Frame: Must be custom designed and fabricated.

(c) Crawlex Drive Assembly: To be purchased as an off-shelf component from such companies as Caterpillar, Rockwell International, Staffa, or Funk Manufacturing.

(d) Main Frame Assembly: Must be custom designed and fabricated.

(e) General Items: Pins: Must be custom designed and fabricated; Bushings: To be purchased as off-shelf components from such a company as the Torrington Company (specifically, needle roller bearing inner races).

(2) Tower/Rotary Head Assembly

(a) Tower: Must be custom designed and fabricated.

(b) Feed Mechanism: Must be custom designed and fabricated, except for the feed cylinders which may be purchased as off-shelf components from such companies as Benton-Harbor, Cross, or Ward Hydraulics.

(c) Chain and Sprockets: To be purchased as off-shelf components from such companies as Rex-Nordburg or Link Belt.

(d) Rotary Head: To be purchased as a standard production item from such companies as Ingersol1-Rand, Bucyrus Erie, or the Robbins Company.

(3) Electrical-Hydraulic system

(a) Hydraulic Fluid Reservoir: Must be custom designed and fabricatien. 
(b) Hydraulic Control Components, such as jack cylinders, valves, filters, hoses, gauges, etc.: To be purchased as standard off-shelf components from such companies as Vickers Inc., Abex-Dennison, Fluid Controls Inc., or Sunstrand Hydro-Transmission.

(c) Electric Motors: To be purchased as standard off-shelf components from such companies as General Electric, Westinghouse, or Louis-Allen.

(d) Electric Motor Starter: Must be custom designed, using standard off-shelf components (e.g. breakers, relays, auto-transformer, timers, switches, etc.)

(e) Electrical Control Components, such as switches; gauges, breakers, auxiliary outlets; ground-fault system, etc.: To be purchased as off-shelf components from such companies as listed under item (c) above.

(f) Hydraulic and Electrical Control Panels: Must be custom designed and fabricated.

(a) Drill Steel: Must be designed and fabricated by a company such as Drilco Industrial to desired specifications.

(b) Drill Bits: To be purchased as off-shelf components from such manufacturers as Reed Tool Company or Kennemetal.

\section{Mechanized Drill Steel Addition/Subtraction System}

(a) Mechanized Handling System, incl. frame components, linkages, pins, rod handling tools, etc.: Must be custom designed and fabricated.

(b) Hydraulic Components: To be purchased as off-shelf items from such manufacturers as listed under item (b) of (3).

(6) Cuttings Removal System

(a) Basic structural Components, incl. surge hopper, catch pan, dust hood, brackers, etc.: Must be custom designed and fabricated.

(b) Conveyor Components, incl. auger, belting, conveyor chain pulleys, hydraulic motors, etc.: To be purchased as offshelf items from full assortment of manufacturers.

(7) Dust Control system: This would not be a new design; rather, an existing and proven system would be purchased in its entirety from a manufacturer such as American Air Filter.

(8) Sound Reducing and Air Conditioned Cab

(a) Basic Cab Design, incl. Built-in Rollover and Roof Fall Protection: Must be custom designed and fabricated.

(b) Accessory Components, such as Air Conditioner, Glass, Sound Deadening Material, Vibration Isolator, Door Latches, etc.: To be purchased as off-shelf items from an assortment of manufacturers. 


\section{SPECIAL CAPABILITIES AND FEATURES OF A CONCEPTUAL DRILLING MACHINE}

For the purpose of this report, the performance/cost characteristics of a conceptual drilling machine will be compared with those of three commercially-available machines that are considered as candidates for the drilling task of the Alpha repository (see Ref. 2). In particular, there are certain features of a drill that would tend to both improve overall drilling efficiency and general safety aspects during a particular job. Table 4.1 presents a summarized comparison of the special features, either currently available (in 1975) or optional, for the BBS-15 Boyles core drill, the Calweld model $150 B$ rotary bucket excavator, the Cyclone $T H-100$ rotary drIll, and the conceptual rotary drill.

None of the three commercial machines have a sound-reducing/airconditioned $\mathrm{cab}$, continuous cuttings-handling system, roof-fall protector, or roll-over protector. A dust control system is an optional feature on the Cyclone TH-100 rotary drill, but unavailable on the other two commercial machines. The BBS-15 Boyles core drill and the Calweld model $150 B$ rotary bucket excavator do not feature high mobility, a rapid set-up time, or roof jack stabilization. The BBS-15 Boyles core drill does not feature a mechanized drill steel handling system, and the calweld model $150 B$ rotary bucket excavator does not have the capability for drilling harder rock types.

It is proposed that all of the special features listed in Table 4.1 be included on the conceptual rotary drill. The inclusion of these special features on a custom-designed machine will obviously increase the capital cost. However, this increase is not anticipated to be any greater, and probably appreciably less in the long term, than the combined cost of the required modifications and associated field trouble shooting for the adaption of those features to a commercially available machine.

In order to accommodate the drilling of rock types that are "harder" than salt, such as limestone, basalt, and granite, the conceptual machine would require design modifications in the: 

(1) thrust capacity;
(2) drill bit;
(3). cuttings removal system.

These modifications are not expected to be either difficult or complicated and can be incorporated as options in the basic detailed design. Furthermore, the cost differential for the exercise of these options is not anticipated to be significant as compared to the unit cost of the basic machine for salt drilling only.

TABLE $\quad$ 4.1

Special Features of Three Commercial Drilling Machines and the Conceptual Drilling Machine

\begin{tabular}{|c|c|c|c|c|}
\hline $\begin{array}{l}\text { SPECIAL } \\
\text { FEATURE }\end{array}$ & $\begin{array}{c}B B S-15 \text { BOYLES } \\
\text { CORE DRILL }\end{array}$ & $\begin{array}{c}\text { CALWELD MODEL } \\
15 O B \text { ROTARY } \\
\text { BUCKET EXCAVATOR }\end{array}$ & $\begin{array}{cl}\text { CYCLONE } & T H-100 \\
\text { ROTARY } & D R I L L\end{array}$ & $\begin{array}{c}\text { CONCEPTUAL } \\
\text { ROTARY DRILL }\end{array}$ \\
\hline $\begin{array}{l}\text { Sound Reducing, } \\
\text { Air-Conditioned } \\
\text { Cab }\end{array}$ & $\begin{array}{c}\text { NO } \\
. \quad .\end{array}$ & NO & NO & YES \\
\hline Dust Control & NO & NO & OPTIONALL & YES \\
\hline $\begin{array}{l}\text { Mechanized } \\
\text { Drill Steel } \\
\text { Handling }\end{array}$ & NO & YES & YES & YESS \\
\hline $\begin{array}{l}\text { Ease of } \\
\text { Mobility }\end{array}$ & NO & NO & YES & YES \\
\hline $\begin{array}{l}\text { Rapid Set-Up } \\
\text { Time }\end{array}$ & NO & NO & YES & YES \\
\hline $\begin{array}{l}\text { Roof Jack } \\
\text { Stabilization }\end{array}$ & NO & NO & . & YES \\
\hline $\begin{array}{l}\text { Continuous } \\
\text { Cuttings } \\
\text { Handling }\end{array}$ & NO & NO & NO & YES \\
\hline $\begin{array}{l}\text { Roof Fall } \\
\text { Protector }\end{array}$ & NO & NO & NO & YES \\
\hline $\begin{array}{l}\text { Roll-over } \\
\text { Protector }\end{array}$ & NO & NO & NO & $Y E S$ \\
\hline $\begin{array}{l}\text { Capability for } \\
\text { Drilling } \\
\text { Harder Rock }\end{array}$ & $Y E S$ & NO & YES & $Y E S$ \\
\hline
\end{tabular}




\section{GENERAL ADVANTAGES OF A CUSTOM-DESIGNED DRILLING MACHINE}

A question that will obviously arise in the minds of the readers of this report is "Do the cost/benefit characteristics of a customdesigned machine significantly outweigh those of a commerciallyavailable drilling machine with the appropriate modifications?". Based on the results of this study and those of a previous one (see Ref. 2), we do feel that the cost/benefit characteristics of a customdesigned drilling machine will significantly outweigh those of a commercially-available machine with appropriate modifications. specifically, section 7 of this report demonstrates that a substantial cost-savings can be achieved by use of a custom-designed machine as compared to the use of any one of three commercial machines without modifications. Due to the specialized nature of the repository drilling task, which involves the high-production drilling of largediameter holes in salt in underground rooms of minimal dimensions, the currently available "off-shelf" machines would not be readily applicable without at least nominal modifications (see Ref. 2). In particular, a chassis for the core drill, with a hoisting mast and stabilization and positioning jacks, would have to be fabricated. The tower and kelly bar of the rotary bucket excavator must be shortened to clear the required 16 foot room height. The Cyclone rotary drill would require shortening of the tower; modification of the drill string from the rotary head to the bit for large-diameter holes; a change of the power pack from diesel to electrical; conversion of the hydraulic system to handle fire-resistant fluids; and chassis modifications to accommodate the storage room dimensions. Dust control would be a problem for both the core drill and the Cyclone rotary drill, although a custom-designed reverse-circulation system for cuttings removal could be adapted to the latter drill. In order to improve the mobility of either the core drill or the bucket drill, adaption to a self-propelled tramming machine would be required. Positioning of the rotary bucket drill al drillhole sites near the rib of a room would be hampered by the one-way swing of the bucket for dumping the salt-cuttings, unless the mechanism was redesigned. An increase in drilling rate above 0.5 foot per minute would be difficult to achieve with the Cyclone rotary drill duc to limitations of the feed and rotary head designs. 
By custom modification of any one of the three commercially-available machines, the overall drilling performance and cost efficiency can be improved, along with achieving a decrease in the number of machines required to complete the repository drilling task. However, we feel that the overall capital cost for the modified machines, including the costs of adding the special features listed in Table 4.1 and the associated breakin problems, would be comparable and probably exceed the capital cost of a custom-designed machine (where the capital cost includes the basic design, fabrication, and testing costs of the prototype machine). Furthermore, there is doubt that, within reasonable cost limits, the modified commercial machine could match the field performance characteristics of a custom-designed drilling machine. In summary, it is our firm opinion that the cost effectiveness of the repository drilling task can be significantly enhanced by the use of a drilling machine that is custom-designed for the job, rather than by use of a commercially-available machine that must be modified or redesigned and subsequently field tested for performance evaluation. 
6. CONCEPTUAL PROGRAM PLAN FOR DESIGN, FABRICATION, AND TESTING

A conceptual program plan for the design, fabrication, and field testing of a prototype drilling machine would involve five phases and twenty-one collective tasks therewith, as illustrated in Figures 6.1 and 6.2. The first two phases, embracing an estimated time duration of eighteen months and four man years of technical effort, involve the conceptual and detailed drill design. The final task of Phase Two entails a GO/NO GO decision on fabrication and field testing of the drill. If a GO decision is made, the final three phases of the project would involve component procurement and unit assembly, field performance testing, and preparation of the service/parts operator manual; this aspect of the overall project will require five man years of technical effort over a time span of thirty months. If a NO GO decision is made, the project would be terminated at the conclusion of Phase Two.

The phase/task time frames for the overall program plan are graphically illustrated in Figure 6.1 and 6.2. A tabulation of estimated man-hours of technical effort and associated labor and material costs is presented in Table 6.1. The five phases and corresponding tasks under each phase may be described as follows:

\section{Phase One: Conceptual Drill Design}

This initial phase of the project, involving a time duration of six months and an estimated one man year of technical effort, includes the following three tasks: (1) definition of the drilling task for the undergruund repository; (2) development of one or more conceptual drill designs; and, (3) selection of the optimum conceptual drill design. The definition of the drilling task requires specification of such 1 tems as desired diameter and depth of the drillholes, desired accuracy of the drillhole alignment, probable storage room, haulageway, and shaft dimensions, probable power source availability, manpower requirements, dust control considerations, MESA-OSHA rules and regulations, and any special requirements. It is anticipated that this information would be predominately provided by the personnel of the office of Waste Isolation and/or their associated consultants. The conceptual design of one or more. drills involves a fundamental machine layout, including the major components, expected operational characteristics, and a preliminary estimate on the onst/performance characteristics. Consideration would be given to various 
.

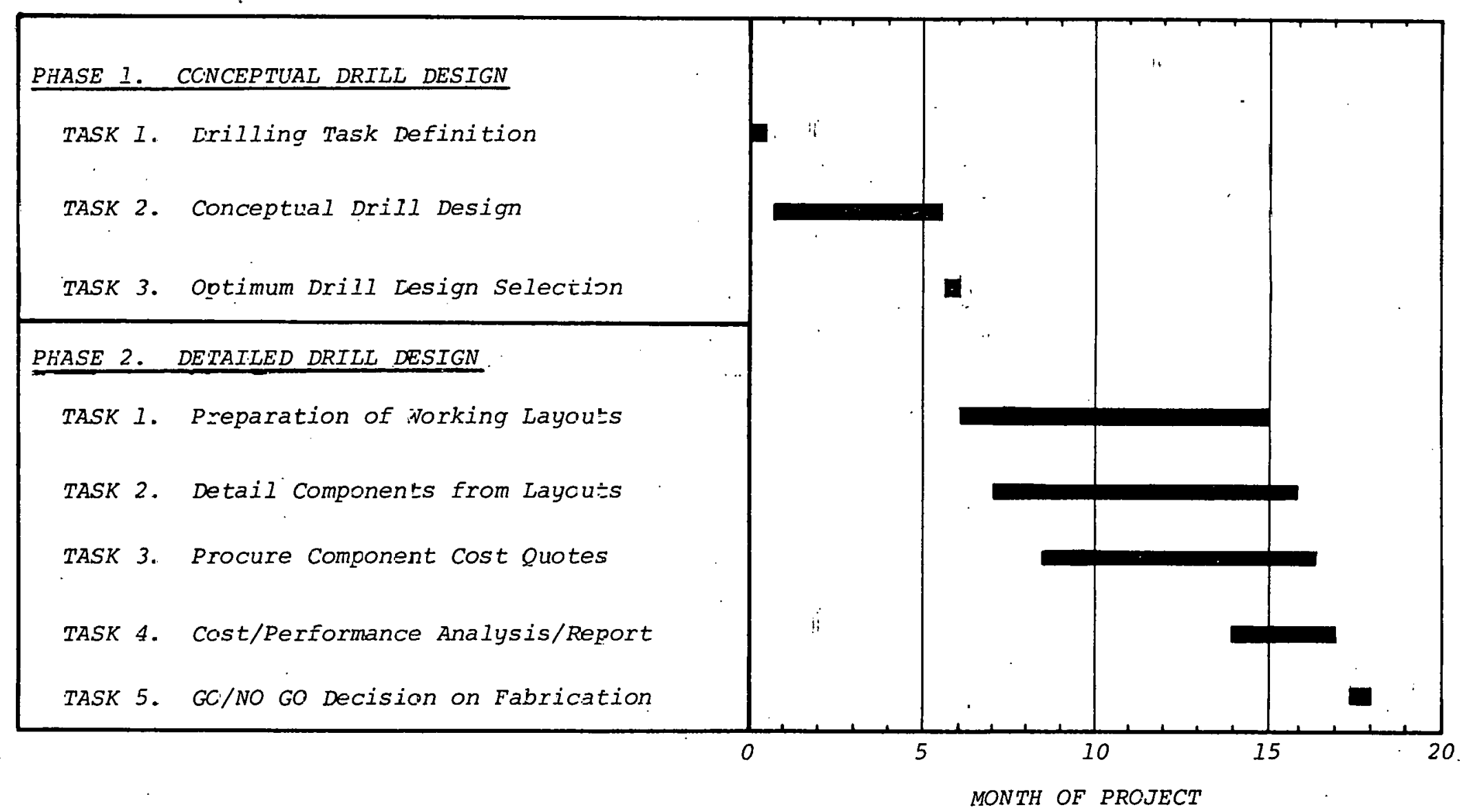

Figure 6.1. Task Definitions for Phases 1 and 2 and Associated Time Frames 


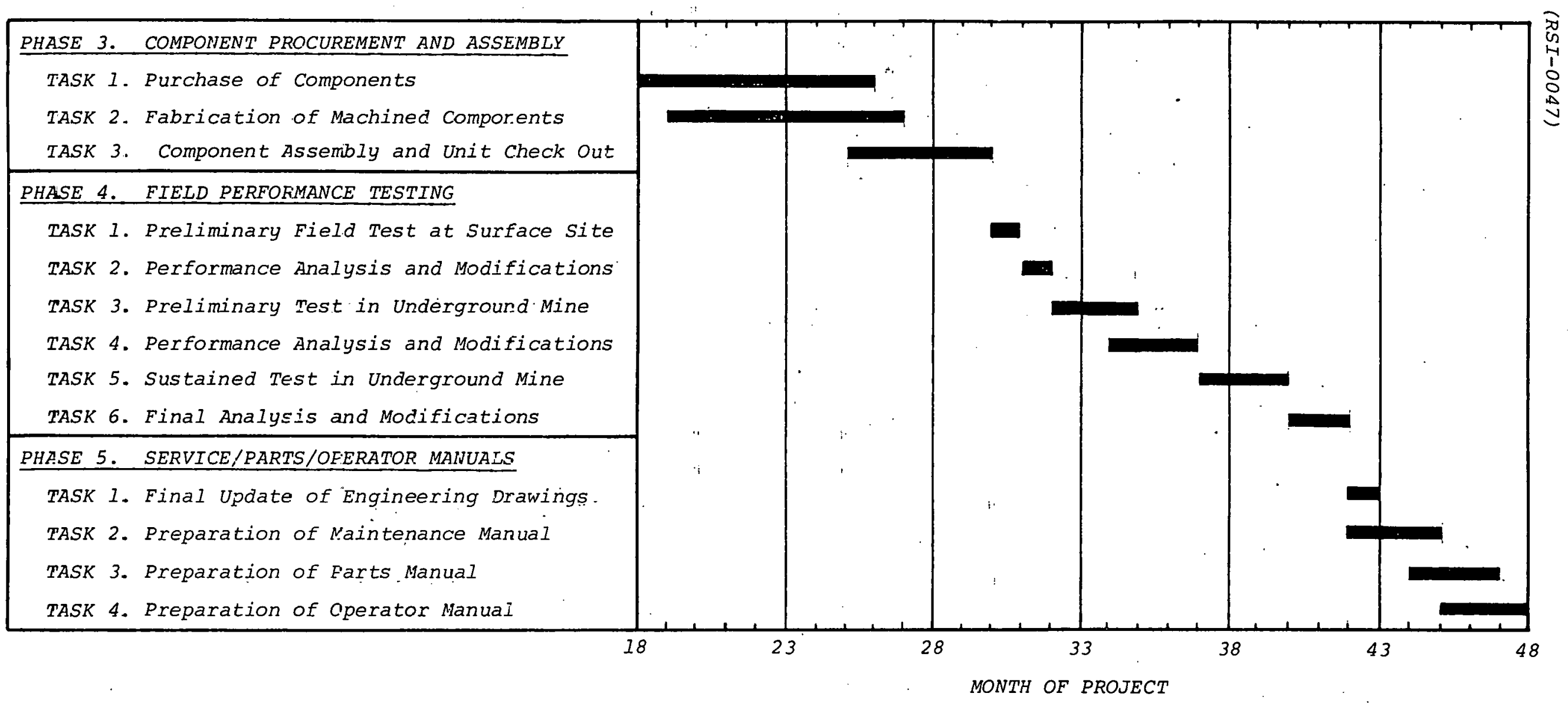

Figure 6.2. Task Definitions for Phases 2, 3, and 4 and Associated Time Frames. 
TABLE 6.1

Tabulacion of Estimated Man-Years of Technical Effort and Associated Labor and Material Costs

for Design, Fabrication, and Testing of a Drilling Machine

\begin{tabular}{|c|c|c|c|c|c|c|c|}
\hline & $M A N$ YEAR/COST ELEMENT & $\begin{array}{l}\text { PHASE I } \\
\text { CONCEPTUAL } \\
\text { DRILL } \\
\text { DESIGN } \\
\end{array}$ & $\begin{array}{l}\text { PHASE } 2 \\
D E T A I L E D \\
D R I L L \\
D E S I G N\end{array}$ & $\begin{array}{c}\text { PHASE } 3 \\
\text { COMPONENT } \\
\text { PROCUREMENT } \\
\text { \& ASSEMBLY } \\
\end{array}$ & $\begin{array}{l}\frac{P H A S E 4}{F I E L D} \\
\text { PERFORMANCE } \\
\text { TESTING } \\
\end{array}$ & $\begin{array}{r}\text { PHASE } 5 \\
\text { SERVICE/ } \\
\text { OPERATOR } \\
\text { MANUALS } \\
\end{array}$ & TOTALS \\
\hline A. & ESTIMATED MAN YEARS OF TECHNICAL EFFORT & 1.00 & 3.00 & 2.00 & 2.25 & 0.75 & 9.00 \\
\hline & $\begin{array}{l}\text { ESTIMATED COSTS } \\
\text { B-1. Technical Labor (Incl. Direct and } \\
\text { Indirect Labor Costs plús Fee; } \\
\$ 40,000 \text { per man year) }\end{array}$ & $\$ 40,000$ & $\$ 120,000$ & $\$ 80,000$ & $\$ 90,000$ & $\$ 30,000$ & $\$ 360,000$ \\
\hline & $\begin{array}{l}\text { B-2. Directly-Purahased off-Shelf } \\
\text { Components }\end{array}$ & 0 & 0 & 115,000 & 0 & 0 & 115,000 \\
\hline & $\begin{array}{l}\text { 3-3. Materials and Fabrication for } \\
\text { Inhouse Designed Components }\end{array}$ & 0 & 0 & 50,000 & 0 & 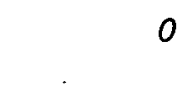 & 50,000 \\
\hline & 9-5. Assembly (Labor and Materials) & 0 & 0 & 30,000 & 0 & 0 & 30,000 \\
\hline & $\begin{array}{l}\text { B-6 Trave1, Computer, \& Misc. } \\
\text { Materials }\end{array}$ & 5,000 & 10,000 & 0 & 45,000 & 5,000 & 65,000 \\
\hline & TOTAL COSTS & $\$ 45,000$ & $\$ 130,000$ & $\$ 275,000$ & $\$ 135,000$ & $\$ 135,000$ & $\$ 620,000$ \\
\hline
\end{tabular}


types of drilling mechanisms, including rotary, drag/auger, rotary percussion, and down-the-hole percussion. In addition, if dust control is a requirement, consideration would be given to various types of collector/ removal systems. The primary objective of the effort through Tasks one and Two is to develop one or more conceptual designs of drills or drilling systems that will best match the required task requirements. The final task of the Phase one is to select the optimum conceptual design of a drilling system. This task will involve consultation with the personnel of the office of Waste Isolation, and basically will require a decision on their part.

\section{Phase Two: Detailed Drill Design}

This phase, requiring a time duration of approximately twelve months and an estimated three man years of technical effort, involves the preparation of the working layouts of the selected conceptual drill design, followed by a detailing of the components from the layout and the procurement of the component cost quotes. Once this information is in hand, a cost/performance analysis can be made and the information in its entirety presented to the personnel of the Office of Waste Isolation for a GO/NO GO decision on fabrication of the drilling rig. If NO GO decision is made, the project would be terminated at this point. Conversely, if a Go decision is made, the final three phases of the project will be initiated; Involving essentially fabrication and testing of the machine.

The first task of Phase Two would involve the development of a primary working layout of the machine, with various sub-assembly layouts as follows:

(a) rotary head;

(b) tower, including the feed system, rod handling system, breakout device, centralizer, and dust hood;

(c) chassis, including the main frame and crawler drive;

(a) opelalur control otation, including the cab (roof fall and roll over protection capability and sound proofing, with air conditioning) and drilling controls (for. a one man operation);

(e) power pack, including electrical/hydraulic interfaces, air compressor and electrical assembly (starter box, ground fault protection, cable reel);

(f) dust control;

(g) cuttings transfer syslem, including conveyor and hopper for moving the cuttings away from the hole collar and then transterring tilem to a load-haul-dump unit or simular unit;

(h) electrical/hydraulic schematics. 
Task Two involves the detail development for the machine and assembiy drawings that are required for procurement in assembly of the drill. Utilizing these detail drawings, Task Three entails obtaining firm cost quotes on the components and preliminary inquiries to various shops for assembly of the machine. Task Four involves a final engineering estimate of the materials/labor assembly costs and an analysis of the anticipated performance of the drill in the field. The final task of this phase would involve submission of the above information to the personnel of the Office of Waste Isolation, consultation with them on various aspects of the information submitted, and a decision for either fabrication and testing of the drilling machine or termination of the project.

\section{Phase Three: Comporint Procurement and Assembly}

This phase, involving three tasks, an estimated time duration of twelve months, and an estimated two man years of technical effort, entails essentially the purchasing of the off-shelf components, the fabrication of any machined components, and the shop assembly and check out of the unit. In essence, the machine is built and checked out for hydraulic leaks, loose bolts, bad welds, etc. prior to field testing.

\section{Phase Four: Field Performance Testing}

This phase involves six tasks, a time duration of twelve months, and an estimated 2.25 man years of technical effort, and includes essentially field testing, modifications, and final performance analyses. Initially, under Tasks One and Two, the machine would be field tested on surface rock of the same or similar consistency as salt, followed by any minor modifications of the design and a performance analysis. Subsequently, field testing of the unit would follow in an underground mine, with a corresponding modification and performance analysis. These field tests would involve disassembly of the machine, transportation of the machine components down a shaft, and undcrground assembly, preferably in either a salt, potash, or trona mine. After some preliminary drilling tests, and subsequent performance and modification analyses, the machine would be subjected to a maximum performance, sustained test, in order to assess productivity rate, reliability, and general capability features of the machine. Pending any final modifications and performance analyses, the machine at this point should be ready for shipment and use at a 
repository site.

Phase Five: 'Preparation of Service/Parts/Operator Manuals

This phase involves four tasks over a time duration of six months, and requires an estimated 0.75 man year of technical effort. In general, the first task would entail a final update on the engineering drawings. The other three tasks involve preparation of the service/parts/operator manuals. In essence, the service or maintenance manual would include the lubrication charts, service records, recommended time changes for filters, etc. The parts or maintenance manual is essentially just a parts book, with the manufacturer identification and accessory information. The operator's manual would be based on the experience obtained in the full scale and sustained field tests, and would be written as much as possible in the language of field operational personnel. 


\section{DRILL PERFORMANCE/COST ANALYSIS}

\subsection{Drilling Simulation}

As the design of the underground radioactive waste storage facility has not been firmly established, a hypothetical or conceptual design is necessary to provide a basis for the cost/performance analyses of both the commercial and conceptual drilling machines. A conceptual mine design has been previously developed by RE/SPEC Inc. (see Ref. 1), and involves a lane (room) and pillar configuration with the rooms grouped into distinct panels. The number of rooms in each panel would be dependent upon the total amount of radioactive waste to be stored and the exact manner and density of storage. The dimensions of a typical room, as illustrated in Figure 7.1, are thirty feet in width and sixteen feet in height, with a storage length of 300 feet.

The radioactive waste will be contained in canisters with a length of ten feet, and a diameter of either ten or twelve inches. It is intended that the canisters will be stored in large diameter (up to twenty inches) vertical drillholes in the floors of the storage rooms. The excavation tonnage, or size, of a given repository design, is based on the storage of the canisters only, and is directly proportional to the number of canisters and inversely proportional to the storage density. In other words, a larger repository would be required if ten-inch diameter canisters were used (since there would be more of the smaller diameter canisters for a fixed volume of waste). Conversely, the repository size requirement would be smaller if two canisters can be stored in each drillhole. Thus, the smallest repository, or lower limit, would correspond to twelve-inch diameter canisters, with two canisters stored per drillhole; the largest repository, or the upper limit, would correspond to ten-inch diameter canisters, with one canister stored per drillhole.

The canister emplacement holes are arranged on a square drillhole pattern, with a distance of three feet from the pillar rib to the center of the outside row of holes, and four feet between centers of adjacent holes and rows of holes. Hence, each room is capable of containing 518 drillholes and storing either 518 or 1,036 canisters, one or two canisters per drillhole, respectively. The depth of the drillholes would be either fifteen or twenty-five feet for one or two canisters per drillhole, respectively, allowing a minimum of five feet of backfill. 


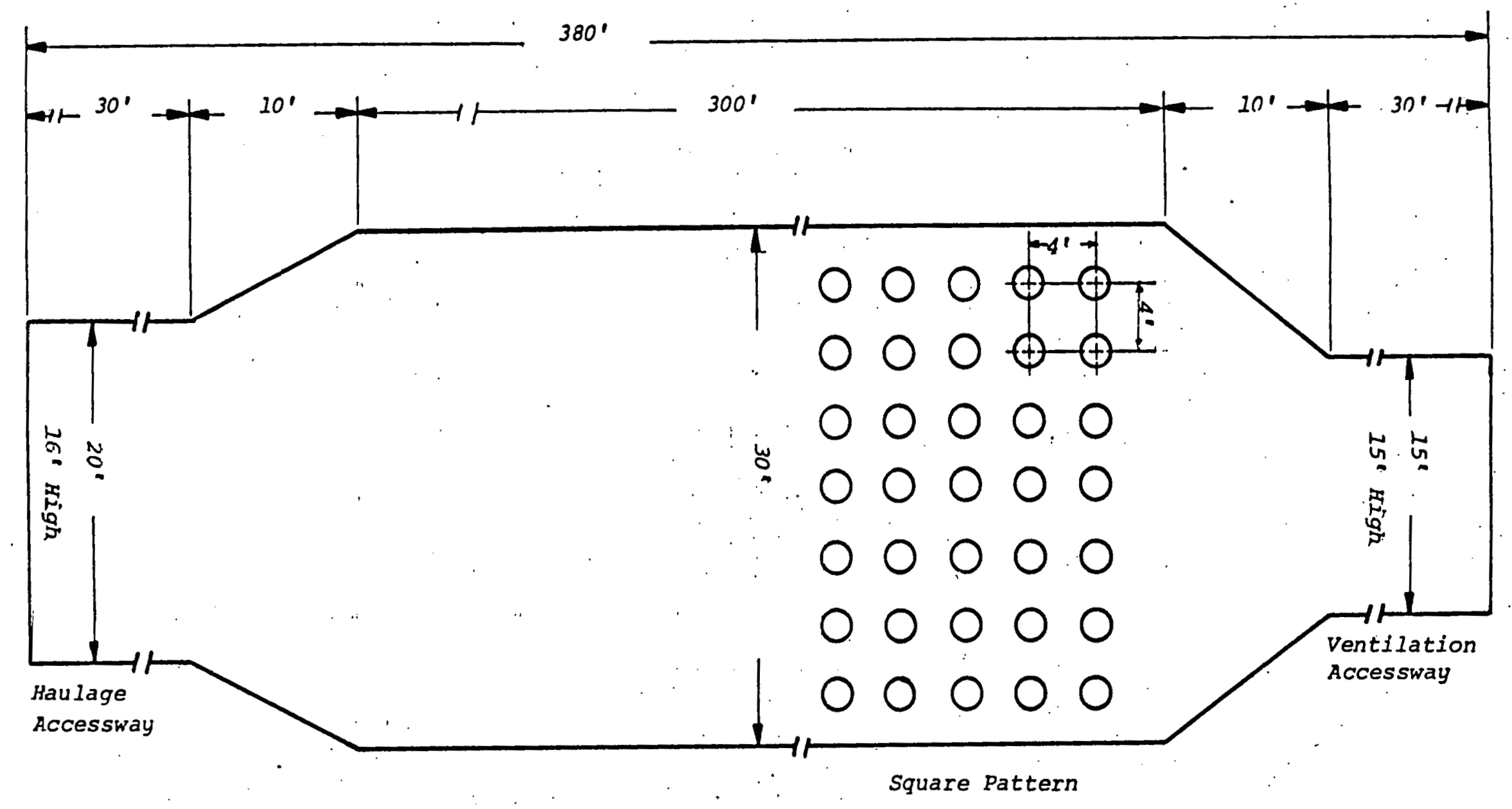

Figure 7.1. Typical Storage Room for the Alpha Repository, with a Square Pattern of prillhoies (See Ref. 1, p. 14). 
Since the simulation of a proposed drilling machine is interconnected with the mine design/operation/scheduling characteristics, a five-panel conceptual repository design, known as the snowflake repository design, and illustrated in Figure 7.2, was selected (see Ref. 1); this particular conceptual mine design has been used in previous drilling simulation studies (see Ref. 2). The snowflake repository design would require 97 rooms for the lower limit of excavation tonnage (corresponding to twelveinch diameter canisters, with two canisters per emplacement drillhole), and 279 rooms for the upper limit of excavation tonnage (corresponding to ten-inch diameter canisters, with one canister per emplacement drillhole). By use of the operational and scheduling characteristics for the Snowflake repository design, in conjunction with the anticipated canister arrival rate, and various operational characteristics of a particular drilling machine, the entire drilling task can be simulated and the cost of excavating the canister emplacement drillholes can be estimated. The drill simulation program yields cost in terms of 1975 dollars. A minimum. of fifteen characteristic parameters of a drilling machine are reguired. The mining simulation program establishes the availability of the rooms for drilling of the canister emplacement holes, in conjunction with the anticipated arrival rate of the waste canisters. These data are used as input to the drill simulation program. The optimum number of drills is established by a successive approximation scheme, with the least cost occurring when all drillis are utilized as fully as possible (i.e. with limited or no scheduled or unscheduled idle time), employing the maximum number of allowable years for completion of a drilling task. 


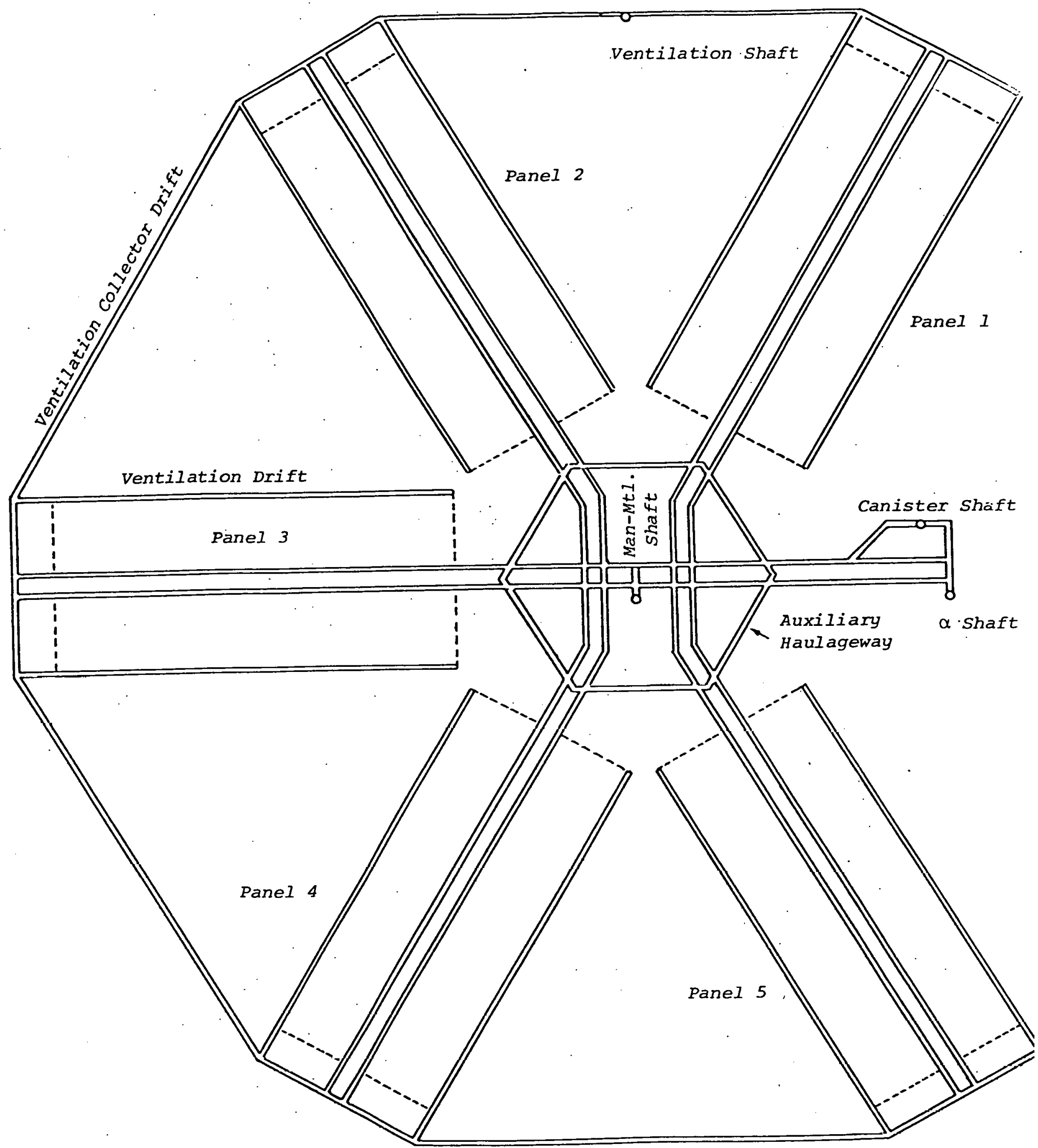

Figure 7.2. Conceptual Layout (Snowflake) for the Underground Facilities of the Alpha Repository (See Ref. 1, p. 4). 


\subsection{Input Parameter Specifications for Drill Simulation Studies}

The input data for the simulation of the three commercial drilling machines and the conceptual drilling machine are listed in Table 7.1. The data for the commercial machines were primarily obtained from the manufacturers (see Ref. 2); in those instances where specific numerical information was not available, reasonable and generally conservative estimates of the parameters were made by the personnel of RE/SPEC InC. It should be mentioned that the estimates are not of the "ballpark" variety, as in excess of thirty manufacturers of drill equipment, drilling accessories, and drill bits were contacted in the study reported under Ref. 2, and approximately 15 drilling machines were evaluated more-or-less in detail prior to in-depth studies of the five candidate drilling machines listed in the report.

The input parameters for the conceptual drilling machine were selected on the dual basis of the information gathered in the above study and the past experience of Mr. Grams of RE/SPEC InC. as a Project Design Engineer for Ingersoll-Rand Inc. In effect, the conceptual machine would conceivably be an electrical-powered rotary drill, mounted on a crawler chassis and utilizing either a drag bit or a tricone pilot bit with hole enlarger, air cuttings removal to a hopper or haulage machine, a mechanized dril! steel addition/subtraction system, and roof stabilization jacks. More specifically, the basis for the values of the input parameters may be summarized as follows:

(1) Drill Penetration Rate $=1 \mathrm{ft} . / \mathrm{min} .:$ Should be feasible for salt drilling with the above bit types if roof stabilization jacks are used, allowing increased thrust and torque on the bit, with a larger capacity rotary head utilized to accommodate the greater torque and thrust.

(2) Drill Rod Length $=10 \mathrm{ft} .:$ Standard length that is both ippropriate and convenient for a room height of 16 feet.

(3) Drill Steel Addition Time $=5 \mathrm{~min}$.: Reasonable estimate if a mechanized drill steel addition/subtraction system is utilized.

(4) Drill steel Subtraction Time $=5$ min.: Same line of reasoning as given for Item (3).

(5) Removal of Cuttings $=0 \mathrm{~min} . / \mathrm{ft}$. : Appropriate for air cuttings removal to a storage hopper or haulage machine. 
INPUT DATA FOR DRILL SIMULATION STUDIES

\begin{tabular}{|c|c|c|c|c|}
\hline SIMULATION INPIUT PARAMETERS & $\begin{array}{l}\text { BBS-15 BOYLES } \\
\text { CORE DRILL }\end{array}$ & $\begin{array}{c}\text { CALWELD } 150 B \\
\text { ROTARY BUCKET } \\
\text { EXCAVATOR }\end{array}$ & $\begin{array}{cl}\text { CYCLONE } & \text { TH-100 } \\
\text { ROTARY } & \text { DRILL }\end{array}$ & $\begin{array}{l}\text { CONCEPTUAL } \\
\text { ROTARY DRILL }\end{array}$ \\
\hline $\begin{array}{l}\text { 1. Drill Penetration Rate } \\
\text { (feet per minute) }\end{array}$ & 1 & 0.6 & 0.5 & $I$ \\
\hline $\begin{array}{l}\text { 2. Drill Rod Length } \\
\text { (feet drilled per addition) }\end{array}$ & . 5 & 30 & 10 & 10 \\
\hline $\begin{array}{l}\text { 3. Drill Steel Addition Rate } \\
\text { (minutes per addition) }\end{array}$ & 1 & 0 & 10 & 5 \\
\hline $\begin{array}{l}\text { 4. Drill steel Subtraction Rate } \\
\text { (minutes per subtraction) }\end{array}$ & 1 . & 0 & 10 & 5 \\
\hline $\begin{array}{l}\text { 5. Removal of Cuttings } \\
\text { (minutes per foot drilled) }\end{array}$ & 2 & 1 & 0 & 0 \\
\hline $\begin{array}{l}\text { 6. Set Up Time. } \\
\text { (minutes at each hole) }\end{array}$ & 45 & 60 & 40 & 20 \\
\hline $\begin{array}{l}\text { 7. Take Down Time } \\
\text { (minutes at each hole) }\end{array}$ & 5 & 20 & 10 & 10 \\
\hline $\begin{array}{l}\text { 8. Tram Time Between Holes } \\
\text { (minutes) }\end{array}$ & 10 & 30 & 15 & 5 \\
\hline $\begin{array}{l}\text { 9. Cost of Drill steel } \\
\text { (per replacement) }\end{array}$ & $\$ 5,000$ & $\$ 5,000$ & 462 & $\$ 30,000$ \\
\hline $\begin{array}{l}\text { 10. Number of Holes before Drill } \\
\text { Steel Replacement }\end{array}$ & 5,000 & 500 & 400 & 50,000 \\
\hline $\begin{array}{l}\text { 11. Cost of Drill Bits } \\
\text { (per replacement) }\end{array}$ & $\$ 5,000$ & $\$ \quad 200$ & $\$ 4,000$ & $\$ 4,000$ \\
\hline $\begin{array}{l}\text { 12. Number of Holes before Drill } \\
\text { Bit Replacement }\end{array}$ & 30 & 3 & 500 & 500 \\
\hline $\begin{array}{l}\text { 13. Cost of Power } \\
\text { (cents per kwh) }\end{array}$ & 2 & 2 & 2 & 2 \\
\hline $\begin{array}{l}\text { 14. Power Consumption Per Hour } \\
(\mathrm{kw})\end{array}$ & 50 & 40 & 50 & 112 \\
\hline 15. Machine Purchase Price & $\$ 30,000$ & $\$ 88,800$ & $\$ 175,000$ & $\$ 300,000$ \\
\hline
\end{tabular}

NOTE: Unless specifically noted below, the input values tabulated above were estimated or determined independently by personnel of RE/SPEC InC. (See Ref. 2).

(1) BBS-15 Boyles Core Dril1: Input values numbered 1, 2, 5, 14, and 15 were supplied by Dresser Industries, Inc. of Dallas., 'I'X.

(2) Calweld 150B Rotary Bucket. Fxcavator: Input values numbered 1, 2, 3, 4, 9, 10, 11, 12, 14, and 15 were supplied by Calweld Division of Smith International, Inc. of Santa Fe Springs, CA.

(3) Cyclone TH-100 Rotary Drill: Input values numbered 2, 9, 10, 11, 12, and 15 were supplied by Cyclone Drill Company of Orrville, $O H$ and by Reed Tool Company of Las Vegas, NV.

(4) Conceptual Rotary Drill: Input values number 11 and 12 were supplied by Reed Tool Company of Las Vega, NV. Specific details for the selection of the other input values are given in section 7.2 of this report.

(5) Item 13. Cost of Power: Based on quote from Southwestern Public Service Company of Carlsbad, $N$. 
(6) Set Up Time $=20 \mathrm{~min}$. per drillhole: Reasonable, and perhaps conservative, estimate for a crawler mounted drill rig (short turning radius due to independent forward/reverse motion of each track), with electrical/hydraulic control system for the roof stabilization jacks.

(7) Take Down Time $=10$ min.: Reasonable estimate for drill rig with a mechanized steel handling system and electrical/hydraulic control system for the roof stabilization jacks.

(8) Tram Time Between Drillholes $=5$ min.: Reasonable time estimate for a drillhole grid spacing of 4 by $4 \mathrm{ft}$. (square).

(9) Cost of Drill steel $=\$ 30,000$ per replacement: The relatively high cost factor is due to the fact that the drill steel would be custom designed and purchased in only limited quantities. The custom design requirement is necessary to accommodate the increased torque and thrust and the mechanized drill steel addition/subtraction system.

(10) Number of Holes before Drill steel Replacement $=50,000$ : This value is one to two orders of magnitude greater than that for any of the other three commercial drilling machines. However, this number is felt to be reasonable on the following basis:

(a) Custom design of the drill steel: A design can be developed to minimize "structural" damage of the rods due to the effects of high thrust and torque and vibration.

(b) Reduction in wear or abrasion: The drill steel abrasion should be minimal due to the relatively low abrasive characteristics of the salt (as compared to highly siliceous rocks), and to the hole centralization provided by the tricone pilot bit.

(11) Cost of Drill Bits $=\$ 4,000$ per replacement: Based on information supplied by Reed Tool Company of Las Vegas, NV.

(12) Number of Holes before Drill Bit Replacement $=500$ : Based on information supplied by Reed Tool Company of Las Vegas, NV.

(13) Cost of Electrical Power $=2 \xi$ per kwh: Based on quote from Southwestern Public Service Company of Carlsbad, NM.

(14) Power Consumption per Hour $=112 \mathrm{kw}$ : Based on a $150 \mathrm{hp}$ requirement. 
(15) Machine Purchase Price $=\$ 300,000$ : This is an average purchase price, based on a requirement of four and six drilling machines over the anticipated lives of the lower-limit and upper-limit repositories, respectively, and an initial design/fabrication/ testing cost of $\$ 620,000$ for the first machine and a unit production cost of $\$ 195,000$ (1975 dollars) for each additional machine, as indicated in Table 7.2. Apart from the initial design/fabrication/testing cost for the first machine, the estimated unit cost of additional machines is comparable to the unit cost of the Cyclone TH-100 Rotary Drill. If twenty drilling machines were required, say for radioactive waste storage in a variety of rock materials, instead of the four or six required for the Alpha repository in salt, the average unit machine cost would decrease to $\$ 215,000$ (in 1975 dollars).

The following information is common to all simulation runs (see also the computer output for the simulation of the conceptual machine presented in the Appendix $A$ ):

(1) Mine Design/Operation/Scheduling and Canister Arrival Rate: snowflake repository design, upper and lower limits of excavation tonnage; see Ref. 1 .

(2) Drilling Drift $=6 \mathrm{in}$. per $30 \mathrm{ft}$. of drillhole.

(3) Production Hours: 6.5 hours at drill site per shift.

(4) Number of Shifts per Day $=2$

(5) Number of Working Days per Year (Average) $=250$

(6) Capital Costs:
(a) Expected Machine Life $=15$ years
(b) Salvage Value $=10 \%$ of Purchase Price
(c) Cost of Capital (Interest or Investment Rate) $=8 \%$

(7) Labor Rates:
(a) Drilling Machine Operator $=\$ 70.00$ per shift
(b) Driller's Helper $=\$ 55.00$ per shift $(20 \%$ average need per shift)
(c) Maintenance Man $=\$ 60.00$ per shift (20\% average need per shift)

(8) Average Cost of Maintenance Material Per Hour of operation $=\$ 6.00$ 
TABLE 7.2

Breakdown of Estimated Costs of the Initial Design, Fabrication, and Testing and Subsequent Production of the Conceptual Drilling Machines for the Alpha Repository (1975 Dollars)

\begin{tabular}{|c|c|c|c|}
\hline MACHINE & PHASE & PHASE DESCRIPTION & $\cos T$ \\
\hline \multirow[t]{2}{*}{ First } & $\begin{array}{l}1 \\
2 \\
3 \\
4 \\
5\end{array}$ & $\begin{array}{l}\text { Conceptual Drill Design } \\
\text { Detailed Drill Design } \\
\text { Component Procurement } \\
\text { and Assembly } \\
\text { Field Performance Testing } \\
\text { Service/Parts/Operator } \\
\text { Manual Development }\end{array}$ & $\begin{array}{r}\$ 50,000 \\
125,000 \\
275,000 \\
135,000 \\
35,000\end{array}$ \\
\hline & \multicolumn{2}{|c|}{ TOTAL ESTIMATED COST. OF FIRST MACHINE } & $\$ 6.20,000$ \\
\hline \multirow[t]{2}{*}{$\begin{array}{l}\text { Second, } \\
\text { Third, cto. }\end{array}$} & 6 & $\begin{array}{l}\text { Production of Machine Units } \\
\text { (a) Components, Materials, } \\
\text { Fabrication, etc. } \\
\text { (b) Labor for Component } \\
\text { Purchases, Fabrication } \\
\text { Inspection, Assembly, } \\
\text { standard operaliunal } \\
\text { Performance Tests, etc. }\end{array}$ & $\begin{array}{r}\$ 150,000 \\
45,000\end{array}$ \\
\hline & \multicolumn{2}{|c|}{$\begin{array}{l}\text { TOTAL ESTIMATED COST (\$ } 1975 \text { DOLLARS) } \\
\text { OF EACH ADDITIONAL MACHINE' }\end{array}$} & $\$ 195,000$ \\
\hline
\end{tabular}




\subsection{Discussion of Drill Simulation Results}

The results of the drill simulation studies for the three commercial drilling machines and the conceptual drilling machine can be best summarized and compared in terms of cost and anticipated field performance. In particular, the cost per foot of hole drilled, the total cost of the drilling task, and the capital machine investment for the four machines are presented in Tables 7.3 and 7.4. In particular, for the lower limit of repository size, the cost per foot of hole drilled can be reduced by a factor of $35 \%$ to $63 \%$ by use of the conceptual drilling machine as compared to the three commercial machines. This reduction can be translated into a savings of at least $\$ 2,000,000$ (in 1975 dollars) in the total costs of the drilling task when compared to the total anticipated costs for the Cyclone TH-100 rotary drill; and, a savings of four to eight million dollars when compared to the Calweld Model $150 B$ rotary bucket excavator and the BBS-15 Boyles core drill, respectively. For the upper limit of repository size, the percentage reduction in the cost per hole drilled is slightly greater than for the lower limit of repository size. Correspondingly, due to the greater number of drillholes required for the upper-limit repository $(144,305$ as compared to 50,246), the savings incurred by use of the conceptual drill could be of the order of at least $\$ 8,000,000$ (in 1975 dollars).

According to Table 7.4, the captial investment in drilling machines is approximately the same for the Calweld Model 150 B rotary bucket excavator, the Cyclone TH-100 rotary drill, and the conceptual rotary drill. However, approximately two or more commercial drills would be required to accomplish the same amount of drilling as one conceptual rotary drill.

By optimizing the capabilities of the conceptual machine for the job, and thereby reducing the number. of arills required, substantial overali savings in personnel and material costs may be realized even though the capital investment may be comparable to that for commercially available machines. For the three commercial drilling machines listed in Table 7.4, the material costs are of the order of three to seventy-seven times greater than the capital investment costs, and the personnel costs are of the order of two and one-half to twenty-five times greater than the capital investment costs. Comparatively, for the conceptual rotary drill, the capital investment and material costs are approximately the same, and the personnel costs are roughly three to four times greater than the capital investment costs. 
- 'Breakdown of Drilling Costs for Three Commercial Drilling Machines and the Conceptual Machine as Determined by Drill Simulation Studies for the Upper and Lower Limits of Waste-Container Drillholes for the Alpha Repository

\begin{tabular}{|c|c|c|c|c|}
\hline \multirow[b]{2}{*}{ Drilling Machine } & \multirow[b]{2}{*}{$\begin{array}{c}\text { Repository } \\
\text { Size }\end{array}$} & \multicolumn{3}{|c|}{ COST BREAKDOWN (1975 $\$)$} \\
\hline & & $\begin{array}{c}\text { Cost } \\
\text { Per Hole }\end{array}$ & $\begin{array}{l}\text { Cost } \\
\text { Per Foot }\end{array}$ & $\begin{array}{c}\text { Total } \\
\text { Cost }\end{array}$ \\
\hline \multirow{2}{*}{$\begin{array}{l}\text { BBS-15 Boyles } \\
\text { Core Drill, } \\
\text { skid Mounted }\end{array}$} & $\begin{array}{l}\text { Lower } \\
\text { Limit }\end{array}$ & $\$ 239.10$ & $\$ 9.56$ & $\$ 12,014,000$ \\
\hline & $\begin{array}{l}\text { Upper } \\
\text { Limit }\end{array}$ & 224.64 & 14.98 & $32,417,000$ \\
\hline \multirow{2}{*}{$\begin{array}{l}\text { Calweld Model } \\
150 \text { B Rotary } \\
\text { Ducket Excavator, } \\
\text { Mounted on } \\
\text { Walking Beams }\end{array}$} & $\begin{array}{l}\text { Lower } \\
\text { Limit }\end{array}$ & 163.90 & 6.56 & $8,235,000$ \\
\hline & $\begin{array}{l}\text { Upper } \\
\text { Limit }\end{array}$ & 158.24 & 10.55 & $22,835,000$ \\
\hline \multirow{2}{*}{$\begin{array}{l}\text { Cyclone TH-100 } \\
\text { Rotary Drill } \\
\text { (Modified), Truck } \\
\text { Mounted }\end{array}$} & $\begin{array}{l}\text { Lower } \\
\text { Limit }\end{array}$ & 133.38 & 5.34 & $6,685,000$ \\
\hline & $\begin{array}{l}\text { Upper } \\
\text { Limit }\end{array}$ & $\begin{array}{c}\text { No } \\
\text { Simulation }\end{array}$ & $\begin{array}{c}\text { No } \\
\text { Simulation }\end{array}$ & $\begin{array}{c}\text { No } \\
\text { Simulation }\end{array}$ \\
\hline \multirow{2}{*}{$\begin{array}{l}\text { Conceptual } \\
\text { Rotary Drill, } \\
\text { Crawler Mounted }\end{array}$} & $\begin{array}{l}\text { Lower } \\
\text { Limit }\end{array}$ & 87.21 & 3.49 & $4,375,000$ \\
\hline & $\begin{array}{l}\text { Upper } \\
\text { Limit }\end{array}$ & 54.30 & 3.62 & $7,630,000$ \\
\hline
\end{tabular}


Breakdown by Lnit and Percentage of Capital, Material, and Personne?

Costs for Three Commercial Drilling Machines and the Conceptual

Drilling Machine, as Determined by Drill simulation Studies for the Upper and Lower Limits of Waste-Canister Drillholes for the Alpha Repository

\begin{tabular}{|c|c|c|c|c|c|c|c|}
\hline \multirow[b]{2}{*}{ DRILLING MACHINE } & \multirow[b]{2}{*}{$\begin{array}{c}\text { UNIT COST } \\
\text { (1975 DGLLARS) }\end{array}$} & \multirow[b]{2}{*}{$\begin{array}{c}R E P O S I T O R Y \\
S I Z E \\
\end{array}$} & \multirow{2}{*}{$\begin{array}{l}\text { NO. OF } \\
\text { MACHINES } \\
\text { REQUIRED }\end{array}$} & \multirow{2}{*}{$\begin{array}{c}\text { INITIAL } \\
\text { CAPITAL } \\
\text { INVESTMENT } \\
(1975 \text { DOLLARS) } \\
\end{array}$} & \multicolumn{3}{|c|}{ TOTAL COST BREAKDOWN (\%) } \\
\hline & & & & & $\begin{array}{l}\text { CAPITAL } \\
\text { COST \% }\end{array}$ & $\begin{array}{c}\text { MATERIAL } \\
\text { COST \% }\end{array}$ & $\begin{array}{c}\text { PERSONNEL } \\
\text { COST \% }\end{array}$ \\
\hline \multirow{2}{*}{$\begin{array}{l}\text { BBS-15 Boules } \\
\text { Core. Drili, skid. } \\
\text { Mounted }\end{array}$} & \multirow{2}{*}{$\$ 30,000 *$} & $\begin{array}{l}\text { Lower } \\
\text { Limit }\end{array}$ & 6 & 180,000 & 1 & 74 & 25 \\
\hline & & $\begin{array}{l}\text { Upper } \\
\text { Limit }\end{array}$ & 12 & 360,000 & 1 . & 77 & 22 \\
\hline \multirow{2}{*}{$\begin{array}{l}\text { Calweld Model } 150 B \\
\text { Rotary Bucket Exaavator, } \\
\text { Mowrted on walking } \\
\text { Beams }\end{array}$} & \multirow{2}{*}{$\$ 88,800$} & $\begin{array}{l}\text { Lower } \\
\text { Limit }\end{array}$ & 7 & 621,600 & 6 & 50 & 44 \\
\hline & & $\begin{array}{l}\text { Upper } \\
\text { Limit }\end{array}$ & 15 & $1,332,000$ & 6 & 51 & 43 \\
\hline \multirow{2}{*}{$\begin{array}{l}\text { Cyclone } T H-100 \\
\text { Rotary Drill (Modified) } \\
\text { Trick Mounted }\end{array}$} & \multirow{2}{*}{$\$ 175,000$} & $\begin{array}{l}\text { Lower } \\
\text { Limit }\end{array}$ & 7 & $1,225,000$ & 15 & 46 & 39 \\
\hline & & $\begin{array}{l}\text { Upper } \\
\text { Limit }\end{array}$ & -- & -- & -- & -- & -- \\
\hline \multirow{2}{*}{$\begin{array}{l}\text { Conceptual } \\
\text { Rotary Drill, } \\
\text { Crawler Mounted }\end{array}$} & $\$ 300,000$ & $\begin{array}{l}\text { Lower } \\
\text { Limit }\end{array}$ & 4 & $1,200,000$ & 19 & 17 & 64 \\
\hline & $\$ 265,000$ & $\begin{array}{l}\text { Upper } \\
\text { Limit }\end{array}$ & 6 & $1,590,000$ & 17 & 23 & 60 \\
\hline
\end{tabular}

*Does not include unit cost of Tramming Machine which is required for the Core Drill. 
In order to evaluate the effects of variations in certain key parameters on cost performance, changes in the set-up time for the drilling machine, the drill steel addition/subtraction time, and the penetration rate of the conceptual rotary drill were studied for the lower limit of repository size. The results of these analyses are graphically presented in Figures 7.3, 7.4, and 7.5, along with the corresponding single data points for the three commercial drills. Specifically, according to Figure 7.3, a $50 \%$ decrease in the anticipated (design goal) set-up time for the conceptual rotary drill would have a negligible influence on the total cost per drillhole; conversely, a 200\% increase in set-up time will increase the total cost per drillhole by only about $2 \%$. Essentially, the relatively minor influence of machine set-up time on cost is due to the fact that one drill at any given point in time is insufficient to handle the scheduled? drilling task, but two drills are more than enough. If only one drill were available to accomplish the drilling task, set-up time becomes a key factor on total cost per drillhole.

As illustrated in Figure 7.4, an $80 \%$ decrease in the anticipated (design goal) drill steel addition/subtraction time for the conceptual drill will decrease the total cost per drillhole by about 3\%; conversely, a 100\% increase in the addition/subtraction time will increase the total cost by about 10\%. Once again, this parameter is keyed to the number of drills that is available for accomplishing the drilling task. It should be noted that although these percentage variations appear relatively small, a $3 \%$ to $10 \%$ variation in either the machine set-up time or drill steel addition/subtraction time correspond to cost variations of $\$ 130,000$ to $\$ 437,500$ for the entire driliing task.

As indicated in Figure 7.5, the total cost per drillhole is strongly influenced by penetration rate, in ar inverse fashion; i.e., as penetration rate decreases, the total cost per hole increases. A significant increase in penetration rate for a rotary drill beyond one foot per minute (design goal) in salt is probably impractical to achieve with large diameter drilling machines at the current level of technology. As a matter of illustration, a $50 \%$ decrease in the anticipated penetration rate for the conceptual drilling machine will cause a 29\% increase in the total cost per drillhole, or an increase of approximately $\$ 1,256,000$ in the total overall cost of the drilling task. Even for a penetration rate of 0.5 feet per minute, the total cost per drillhole with the conceptual machine is still about 16\% less than with the nylone $T H=100$ rotary drill, or an overall cost difference of about $\$ 1,045,000$ for the entire drilling task. 


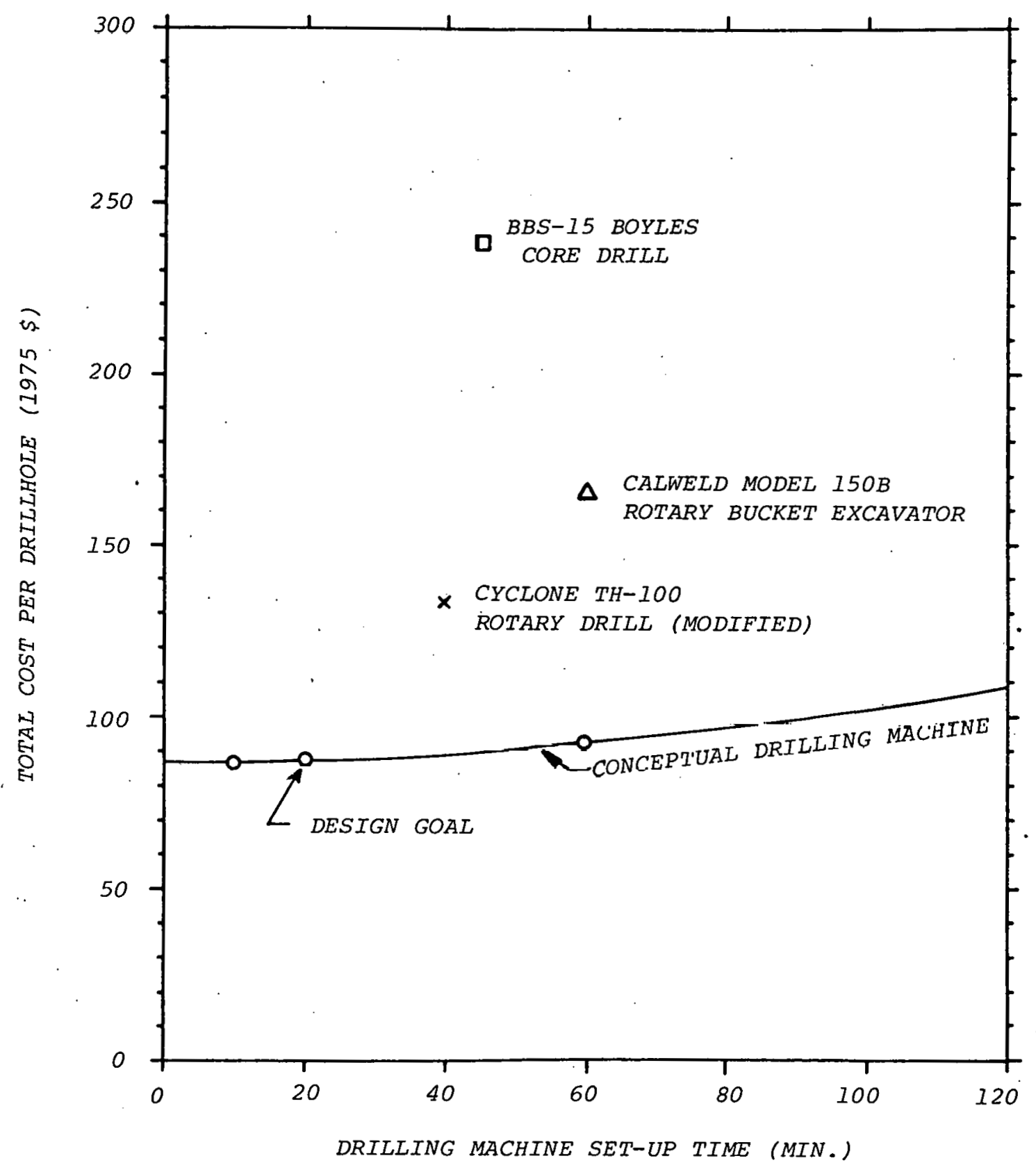

Figure 7.3. Graphical Representation of the Effect of a Variation in Set-Up Time of the Drilling Marhine on Tutal Cost per Drillhole (LowcrLimit Repository Size). 


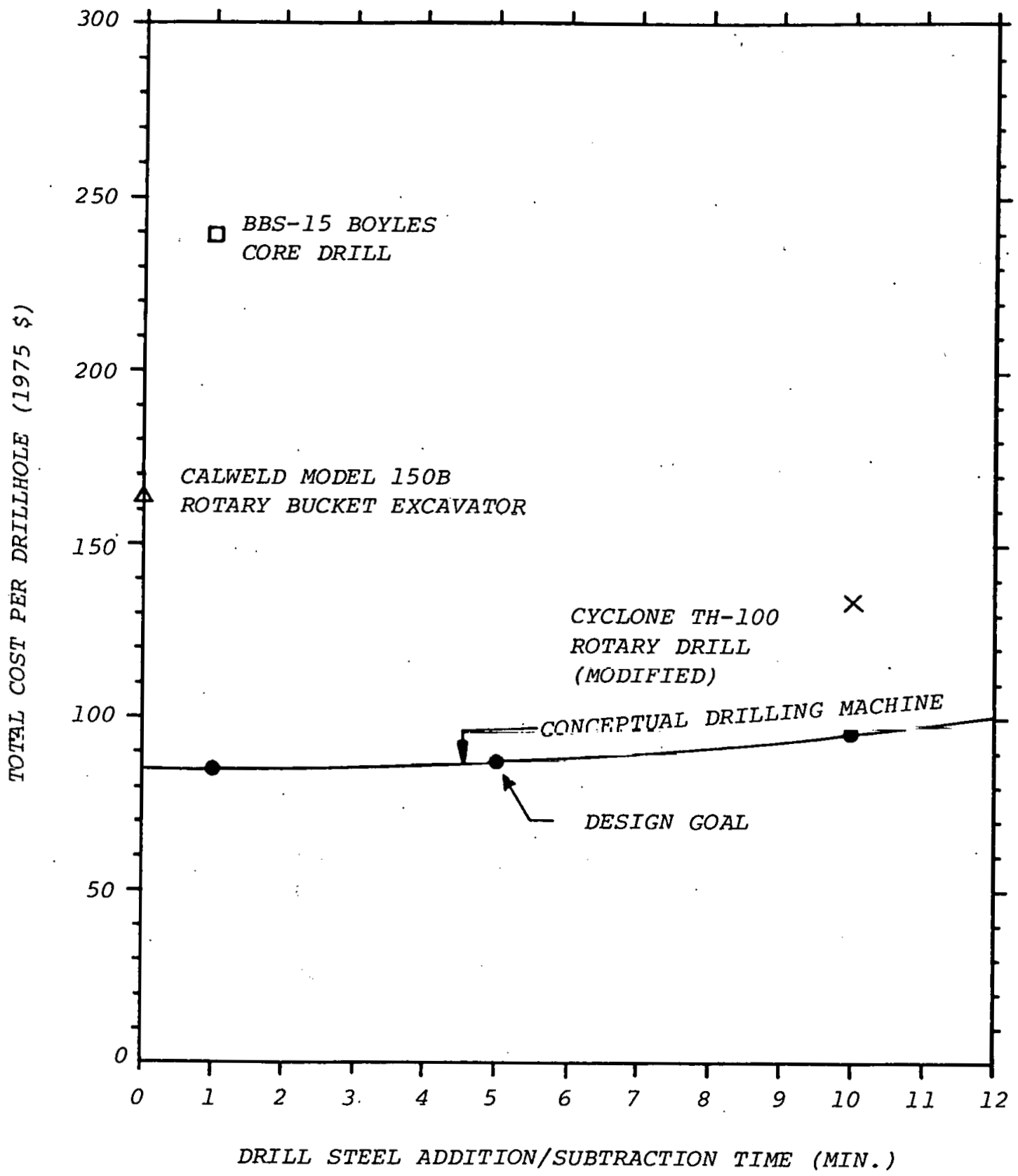

Figure 7:4. Graphical Representation of the Effect of a. Variation in Drill Steel Addition/Subtraction Time on Total cost per Drillhole (LowerLimit Repository Size). 


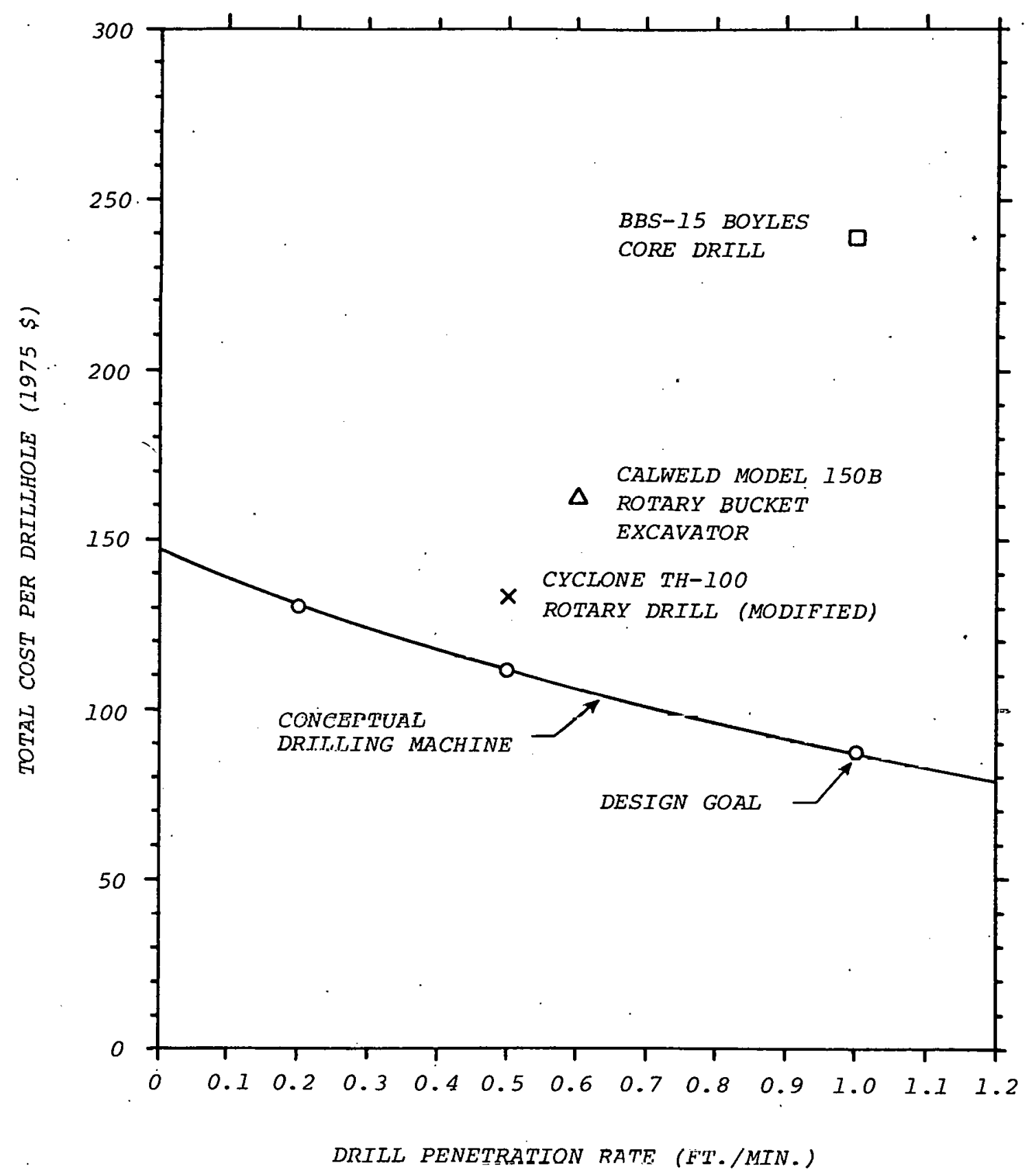

Figure 7.5. Graphical Representation of the Effect of Drill Penetration Rate on Total Cost Per Drilihole (Lower-Limit Repository Size). 


\subsection{Concluding Comments}

The preceding drill performance/cost simulation study has permitted a comparative analysis of three drilling machines that may be considered as candidates for the repository drilling task and the conceptual rotary drill. The simulated operation of each drill is based on fifteen key input parameters for the drilling machine and associated time-wise operational parameters for a conceptual repository mine design. The values of the input parameters for the commercial drills are in general based on information supplied by the manufacturers; conversely, the values of the input parameters for the conceptual drill are generally based on experience and anticipated performance, as related to the specific needs. of the drilling task. One may question the values that were selected for the conceptual drill, and the influence therewith on overall cost and performance. However, the parameter variation studies do provide some definitive insight.into the overall effects of machine set-up time, drill steel addition/subtraction time, and penetration rate. The composite results indicate that even the "worst case" situation for the conceptual drill would yield lower costs and better performance than any of the three commercial drilis. In fact, for the worst case situation under the goals and requirements of the repository drilling task as presently defined, the cost savings would be of the order of several million (1975) dollars. 


\section{LIST OF REFERENCES}

(1) Grams, W. H.: "Design Aspects of the Alpha Repository: II. Conceptual Layouts of Underground Storage Facilities", Technical Memorandum Report RSI-0028, Prepared for Holifield National Laboratory under. Subcontract No. 4269 with Union Carbide Corp., Nuclear Division (June 30, 1975), $74 \mathrm{pp}$.

(2) Ellis, D. B. and Grams, W. H.: "Design Aspects of the Alpha Repository: $V I$. Selection and Cost Analysis of Large Hole Drilling Equipment", Technical Memorandum Report RSI-0032, Prepared for Holifield National Laboratory under Subcontract No. 4269 with Union Carbide Corp., Nuclear Division (June 30, 1975), 66 pp. 
SIMULATION OUTPUT FOR THE CONCEEPTUAL DRILLING MACHINE (SNOWFLAKE REPOSITORY LAYOUT; LOWER LIMIT)

\section{LARGE HOLF DRILLING EQUIPMENT}

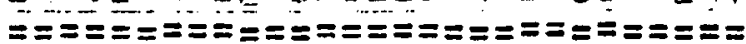

TNFORMATION ANI OHILL CYCLE SIMULATION

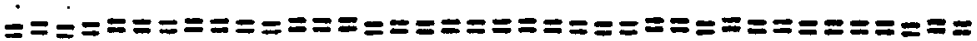

GENERAT INFDTRAATT TN

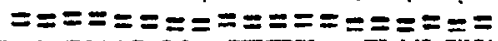

DPILL TYPE. .

\section{ROTARY}

AIT TYPF..

DRAG, TRTCONE

NAME,$M O D E L .$.

RE/SPEC CONCEPTUAL/MODEL ALPHA-l

PHYSICAI O OPEDATTMG CHARACTERISTICS

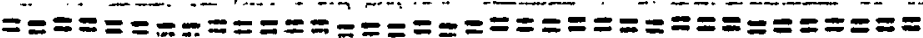

PUILYC \& I > . .

UNDE TERMINED

UFTEHT (LBS)

$$
3000
$$

PONFR SNUJCE..

ELECTRIC

SPF TIFIS DETAILS ON DRILLING METHDO..

DRAG BIT WITH AUGER CUTTINGS REMOVAL

OP TRICONF PILOI AIT WITH HOLE ENLARGER

CUTTINTS REMUVAL METHON SUGGESTEU.-

AIR OR AUGER

SPFCTII. MANPOWFR REOUIREMENTS FUR OPERATION OR MATNTENANCE. . N!)NE/NO SPECIAL SKTLLS NECESSARY FOR

EITHER DRTLLING OR MAINTENANCE

SOFRTAL VENTILATION RFIUUIREMENTS.. NONE

HOJGTTHS SPECIFICATIONS - BREAKDOWN OF COMPONFNTS. 
DRILLIAIR SPECTFICATIONS

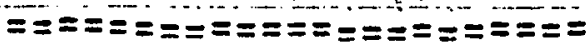

HOI.F NIAMETER (INCHES) .

20

HOLF NEOTH (FEET)

HOLF CPACTNG TFEET ON CENTERT -

4

VIIMAFR OF HOLES PER ROOM..

518

DRJILTNA DRTFT (INCHES IN 30 FEET)

6.0

OQILLINATA DTES

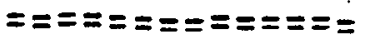

DRIIL PENETQATION RATES (FEET PER MINUTE).. I.O

TRILL STEEL NEEDED (FEET DRILLEU PER ARIIITIION)

$10 \cdot 0$

1)RIIL STEEL ADNITIUN RATE (MINUTES PER ADDITION)...

NRIIL STEEL SUBTRACTION RATE (MINUTES PER REMNVAL) . 5.0

REMIVIAI. OF CUTTINGS IN ADDITTON TO TIME REQUIRFN

FOR DFNETRATION (MINÜTES PER FOUT DRILLEDI...

0.0

MAIVTFRIANCE TIME (MINUTES REQUIRED PER HOUR OF DRILL DPEDATTINI $\cdots$ 5

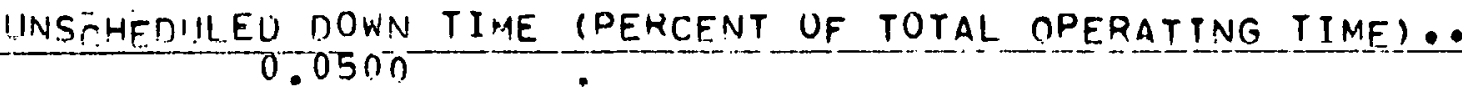

SFT-IID TIME (MINUTES TO SET IJP URILL AT EACH HOLE) •. 20.0

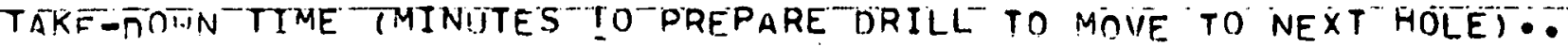
10.0

TRA A TISE BETINEE HOLES (MINIJTES) • 
(RSI-0047)

$$
5.0
$$

DROMUTTTION HUURS (HOURS AT DRILL SITE PER SHIFT)..

$$
6.5
$$

COSTS - PFRSOANIFL

$============$

NPETATIIN MAN A TTITLE, NUMBER PER DRILLPER SHIFT, SHTFT RATEI:OPERATOR

$$
70.00
$$

OPFPATION MAN B (TITLE, NUMBER PER DRILL PER SHIFT, SHIFT RATE) DRILLFRS HELPER $5 \overline{5} .00$

DPE FATINN MANC TITLE, NUMBSER PER DRILL PER SHIFT, SHIFT RATE) • NOT NEEDEN

$$
0.00
$$

MATUTFNANCE MAN (NU:ABER PER DRILL PER DAY, SHIFT RATE).:

0. 20

60.00

COSTS - AATFRTA!

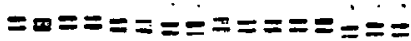

COST AF DRILL STEEL (DULLARS PER REPLACEMENT).. 20000.00

TIIACFR OF HOLES BEFORE ORILL STEEL REPLACEMENT . 50000

COST NF ORILL RITS IDOLLAKS PER DFPLACFMENTI. 4000.00

NUMAFR OF HOLES BEFORE DRILL HIT REPLACEMENTI ..

$$
500^{\circ}
$$

COST OF POWER (CENTS PER KWT..

$$
2 \cdot 00
$$

OOUER CONSU:IPTION PER HOUR OF OPERATION (KW). 112.00

COSTT IF MAINTENANCE MATERIQL. PER HOUR OF OPERATION. G.OOO 
MACHTNE PIJRCHĀSE PRTICE... 300000.00

MACHINE LIFE EXPECTFD.-

15

SALVAGF VALUE (PERCENT OF PURCHASE PRICE) • $0.100 ?$

COST AF CAPITAL (INTEREST OR INVESTMENT RATE!.. 0.0800

NUMAOFR IF DRILLS REOUTRED PER YEAR (YYEAR NOMBEA IN PARENTHESEST.

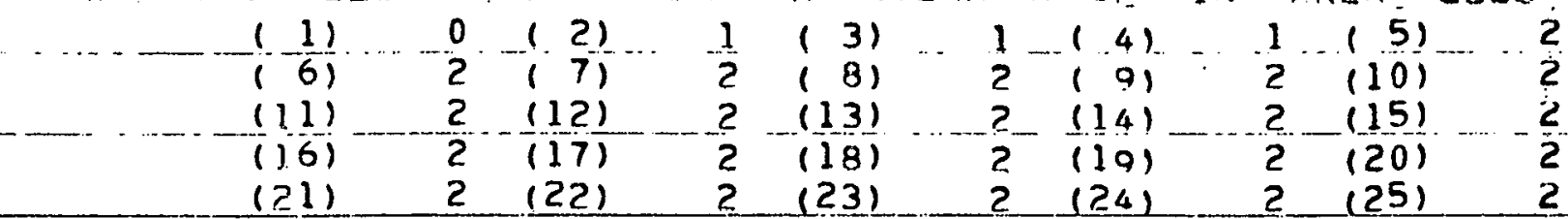

DRILL MABTLTTY

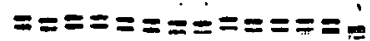

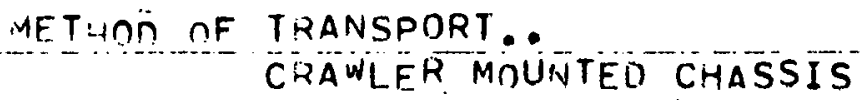

ROOW TRAM IIME (OAYS)

PANFI TOAM TIME IOAYSI ?.00

HUMMSFE OF DRILLS ALLOWED IN A RUOM.

CANISTER AAPIYAI.

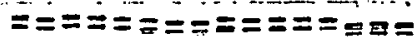

CANTSTETSS PER YEATR TYEAR NUMBER IN PARENTHESESSI..

$\begin{array}{lrlllllllll}\text { (1) } 1545 & (2) & 525 & (3) & 573 & (4) & 684 & 5 & 859 \\ (6) & 1066 & (17) & 1289 & (18) & 1512 & (9) & 1767 & (10) & 2038 \\ (11) & 2340 & (12) & 2643 & (13) & 2993 & (14) & 3375 & (15) & 3784 \\ (16) & 4267 & (17) & 4792 & (18) & 5382 & (10) & 6019 & (20) & 6687 \\ (21) & 7437 & (22) & 8248 & (23) & 9140 & (24) 10127 & (25) 11130\end{array}$

NIIMAFO TF CANTSTERS PER EMPLACEMENT HOLE.. 
(RSI-0047)

MINE DFSIGN, ODFRATION / SCHEDULING

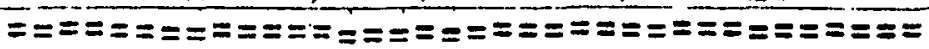

NAMF OF MINF -

SIVOWFLAKE - LOWEK LIMIT

NIJMAFR OF PANELS.-

MITAOFO OF ROOOSS PER PANEL (PANEL MINING

SEOIFNCE IN PARENTHESESI

$\begin{array}{rrrrrrrrrrr}(1) & 19 & (2) & 19 & (3) & 19 & (4) & 20 & (15) & 20 \\ (6) & -0 & (.7) & -0 & (8) & -0 & (9) & -0 & (10) & -0\end{array}$

NIIMAFR AF YEARS OF SCHEDULED OPERATION. 25

NUMMFF OF WORKIN̈G OATYS PER YEAR (AVERÄGE) •.

250

NUMERER AF SHIFTS PER DAY

POOOA AVALABILITY.:

DATA IS SUPPLIED RY MINING SIMULATION PROGRAM

THE FOI OWTWG NOILLING DATA IS THE RESULT OF A SIMULATION OF A

DATLLTIG PROCESG DASEO ON THE ABOVE DOATA.

DRILLJNG RATES

$==\Xi=ニ=ニ=ニ=ニ=$

3ASF O ON RUOM AVAILABILITY, DRILLING WILL START..

UAY 58 YEAR ?

NPIIL TTME PER HOLE (MINUTES).-

$55 \cdot 00$

MAXTMIIM NIIMSER OF HOLES PER TAY.

8.01

COMOARISON OF NIIMBEL OF CANISTER EMPLACEMENT HOLES NEED PER YEAR AND

EMP, $\triangle$ CEAENT ROLES MANE AVAILABLE BY THIS DRILL, I ALSO SEE GRAPH I...

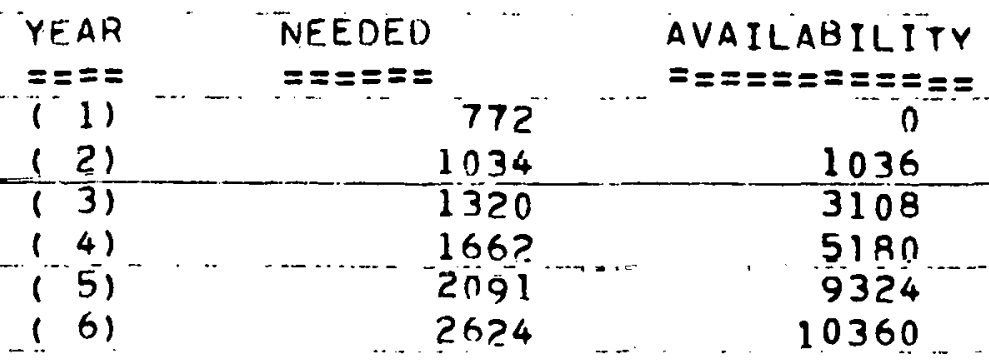


(RSI-0047)

$\begin{array}{rrr}(7) & 3268 & 12950 \\ (8) & 4024 & 16058 \\ 19) & 4907 & 18648 \\ (10) & 5926 & 20202 \\ (11) & 7096 & 20720 \\ (12) & 8417 & 23310 \\ (13) & 9913 & 26418 \\ (14) & 11600 & 29008 \\ (15) & 13494 & 30044 \\ (16) & 15627 & 31080 \\ (17) & 18023 & 33670 \\ (18) & 20714 & 36778 \\ (19) & 23723 & 39368 \\ (20) & 27066 & 39886 \\ (21) & 30784 & 41440 \\ (22) & 34908 & 44548 \\ (23) & 39478 & 4738 \\ (24) & 44541 & 50246 \\ (25) & 50106 & 50246\end{array}$

DRILLING EFFICIFN!

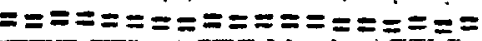

NUMRFR OF IDLE DRILL DAYS PER YEAR (ALSO SEE GRAPH)

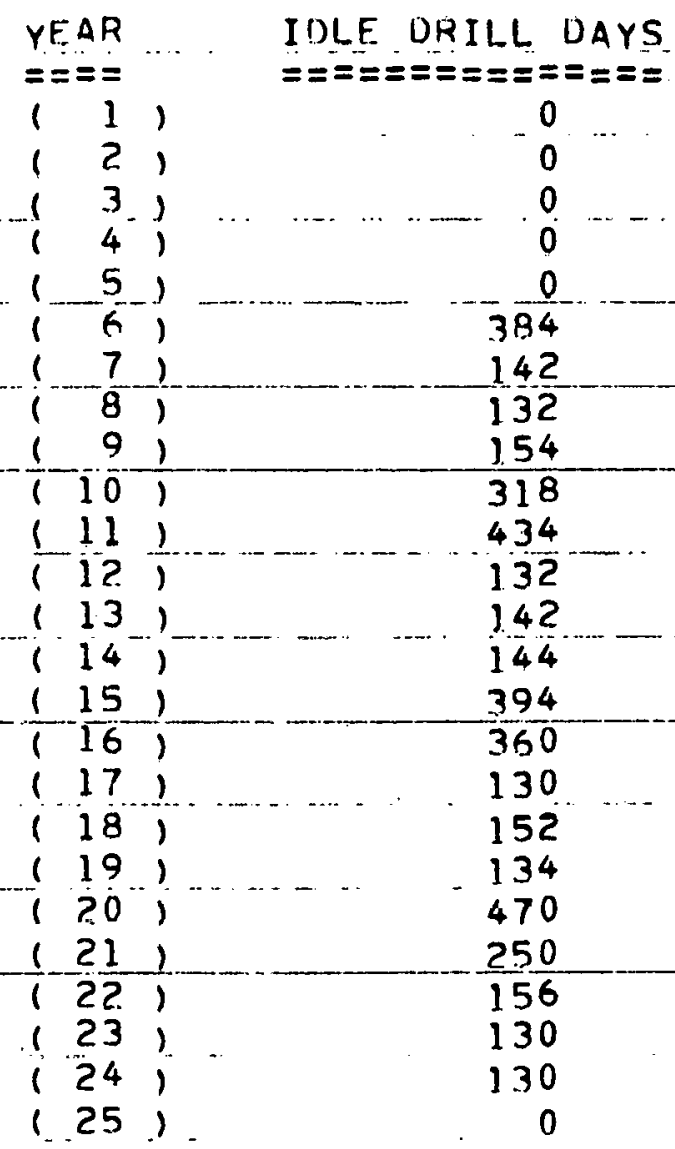

PER CENT OPERATION TIME PER YEAR (ALSO SEE GRAPH).. 
(RSI-0047)

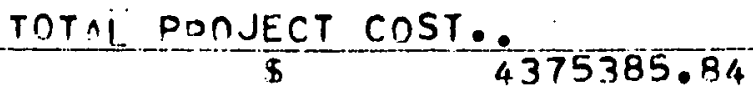

TOTAL PANDECT COST BROKEN INTO:-

OPERATION COST $\ldots$
LABOR COST .
MATERIAL COST..

An

MAINTENANCE COST.. S

LABOR COST
MATERIAL COST..

3134519.84

$\frac{2687500.00}{447019.84}$

$40494 \bar{R} .00$

129000.00
275946.00

CAPITAL COST.. $8359 ? 0.00$

AVE PAGE COST PER HOLE OVER PROJECT..

$\$$ $87 \cdot 21$ 


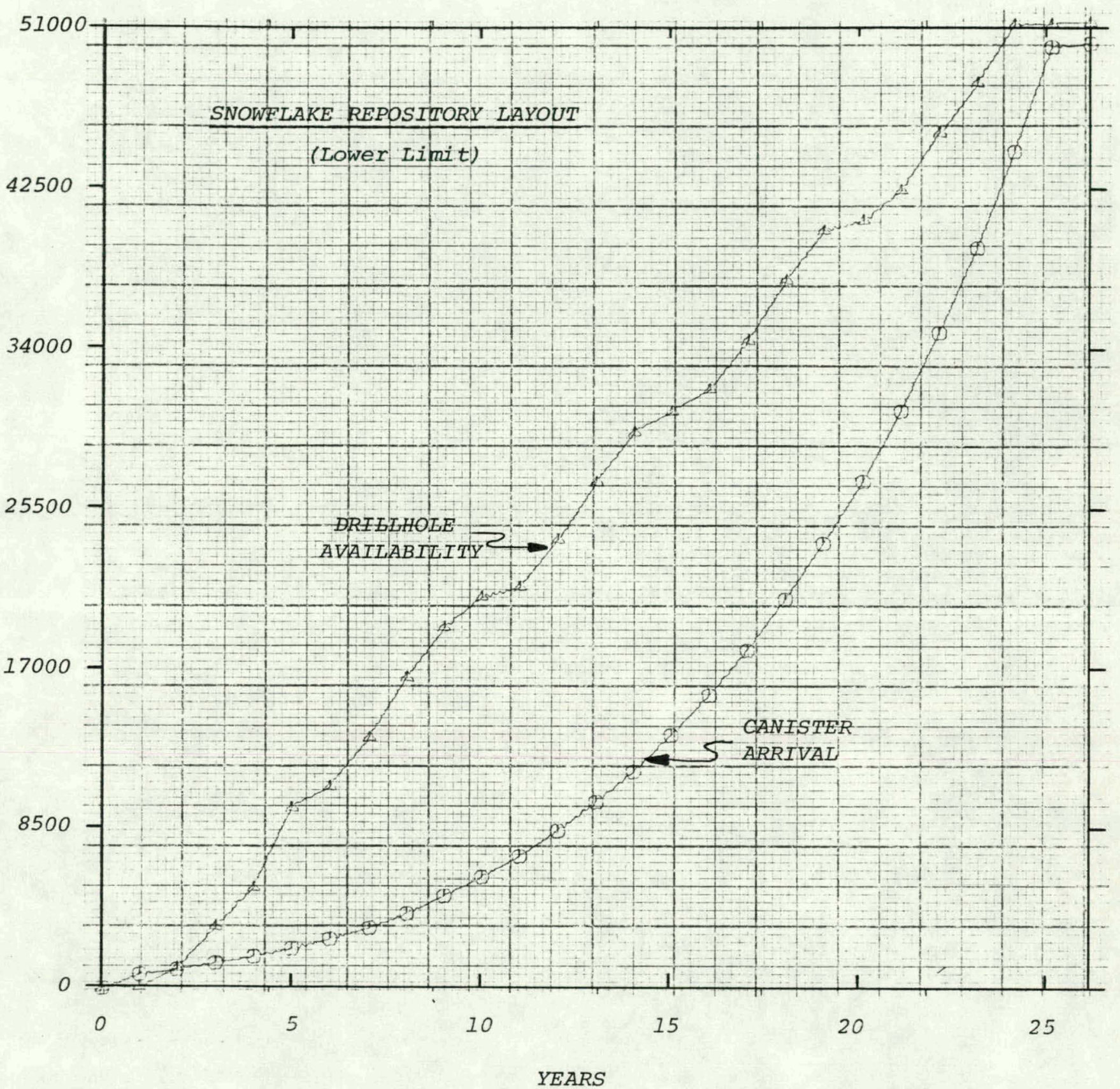

Figure A.1. Graphical Representation of the Timewise Accumulation of Waste Canisters and the Corresponding Accumulation of Drillholes Produced by the Conceptual Drilling Machine. 


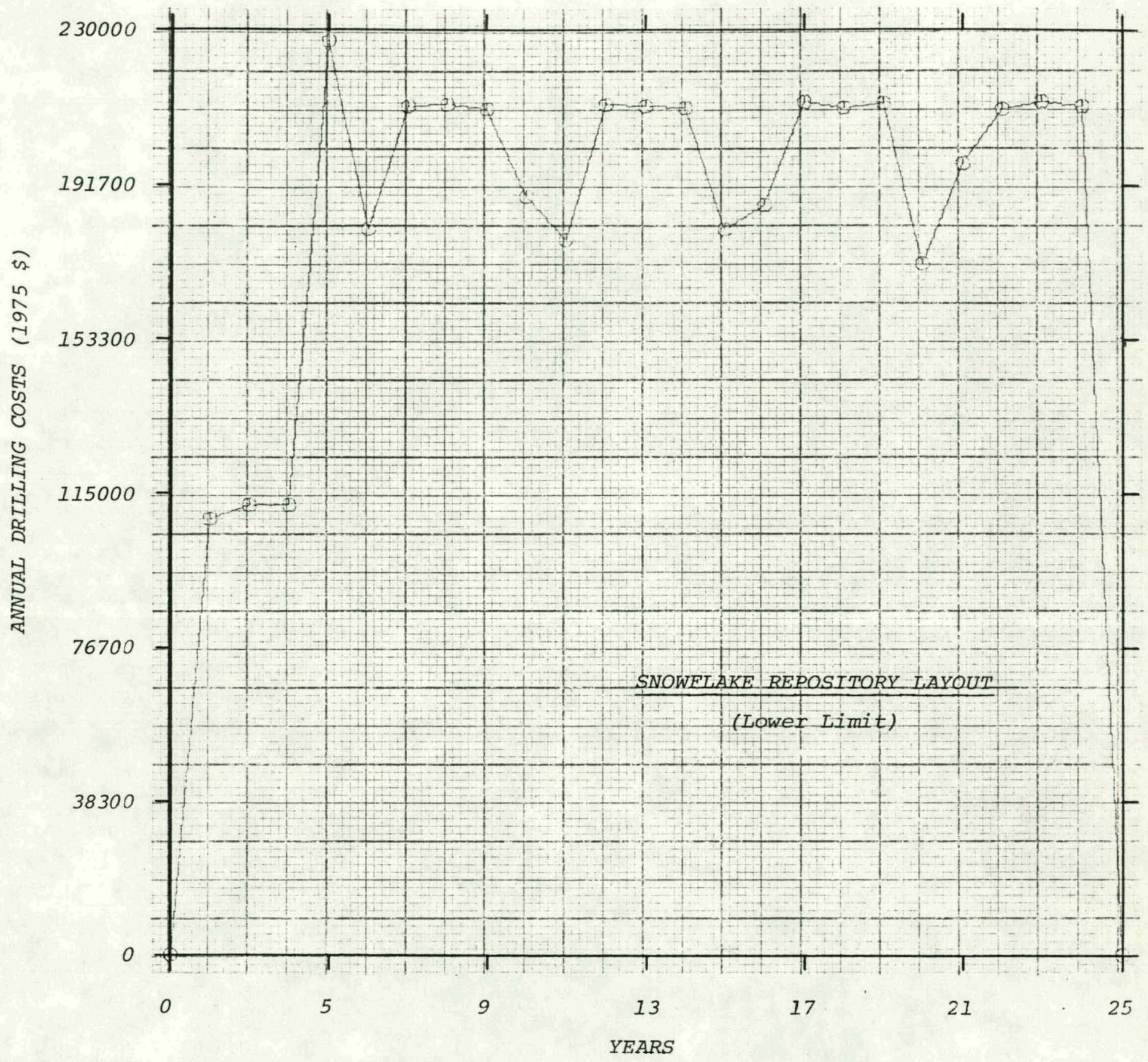

Figure A.2. Graphical Representation of the Projected Annual Drilling Costs (1975 Dollars) for the Conceptual Drilling Machine. 


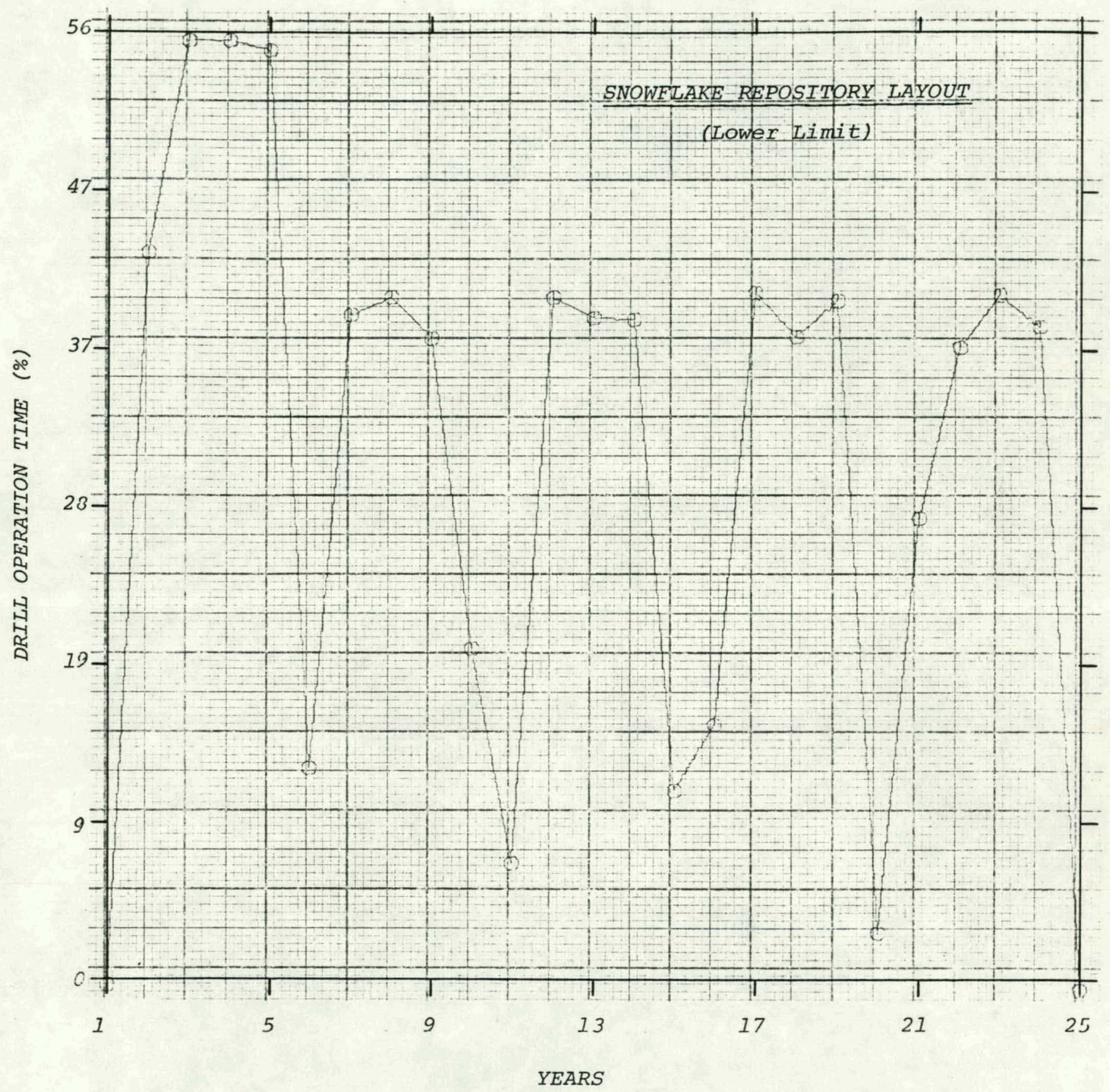

Figure A.3. Graphical Representation of the Percentage Operation Time on an Annual Basis for the Conceptual Drilling Machine. 